\title{
MORPHOLOGICAL STRUCTURE AND PHONOLOGICAL DOMAINS IN SPANISH DENOMINAL DERIVATION
}

\author{
RICARDO BERMÚDEZ-OTERO \\ University of Manchester
}

Forthcoming in: Colina, Sonia \& Fernando Martínez-Gil (eds), Optimality-theoretic studies in Spanish phonology. Amsterdam: John Benjamins.

\section{Introduction ${ }^{1}$}

In Spanish, nominal words fall into a number of inflectional classes, each characterized by a particular stem formative: ${ }^{2}$ thus, $o$-stems bear the formative /-o/, $a$-stems bear the formative /-a/, and $e$-stems bear the formative $/-\{\mathrm{e}, \varnothing\} /$ (less frequently, /-e/). ${ }^{3}$ Together, these three core classes comprise the vast majority of Spanish nouns and adjectives; athematic stems, which lack stem formatives altogether, are comparatively rare.

(1)

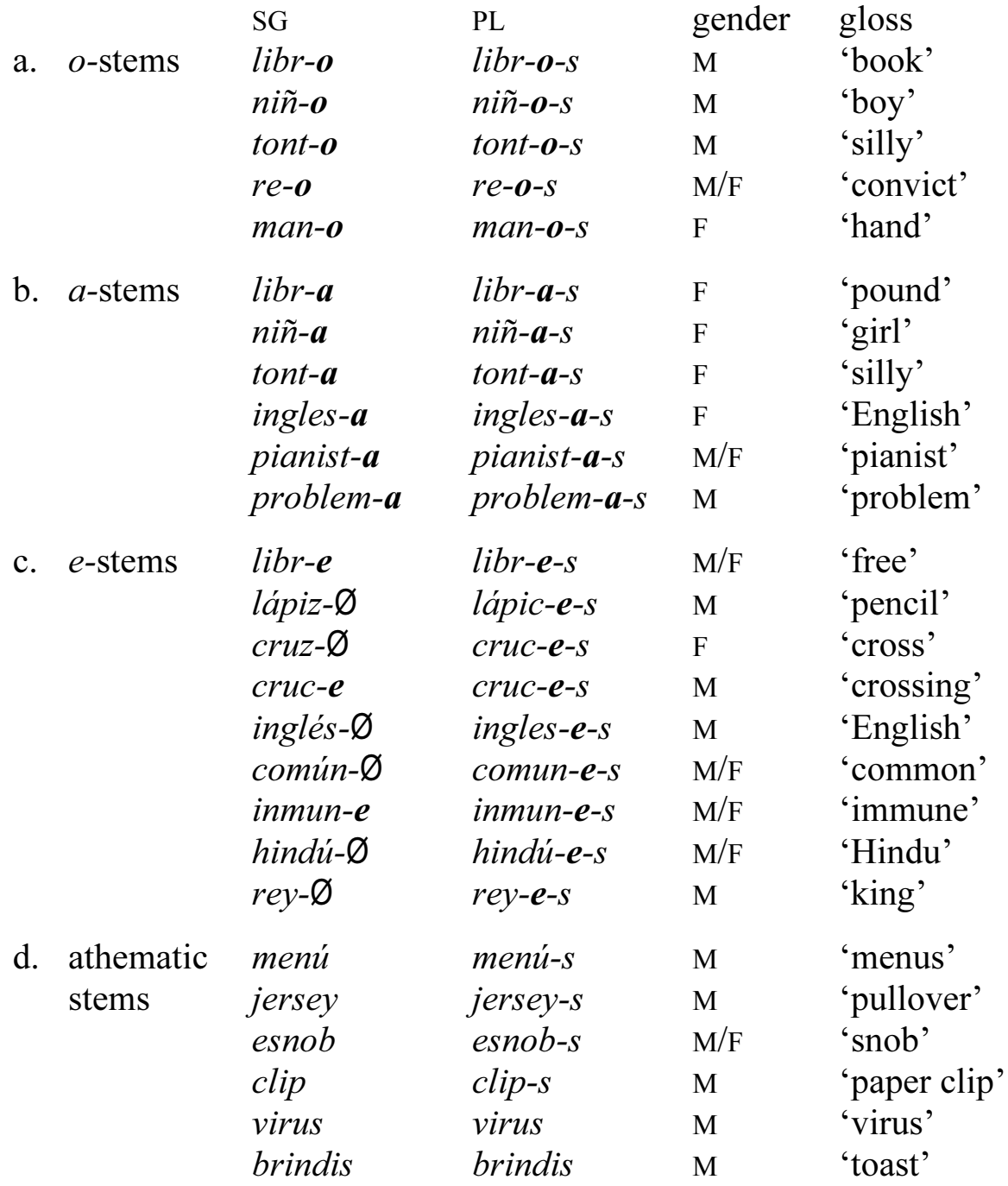

Establishing the exact inventory and underlying distribution of nominal stem formatives is a key task for Spanish morphophonology, for it is impossible to analyse the phonotactics or the metrical system of the language without making crucial assumptions about the phonological behaviour of these elements. Discussions of Spanish stress assignment illustrating this link 
include Harris (1983: 114-116, 1992: 75-76), Oltra-Massuet and Arregi (2005: §3.1), and Roca (1988: 416, 1991: note 11, 2005: 357-358), among many others.

On the surface, nominal stem formatives seem never to occur before derivational suffixes. This is one of their most salient properties.

\begin{tabular}{|c|c|c|c|c|}
\hline base & & derivative & & \\
\hline $\begin{array}{l}\text { man-o } \\
\text { problem-a } \\
\text { nub-e }\end{array}$ & $\begin{array}{l}\text { 'hand' } \\
\text { 'problem' } \\
\text { 'cloud' }\end{array}$ & $\begin{array}{l}\text { man-az- } a \\
\text { problem-ón- } \varnothing \\
\text { nub-os-o }\end{array}$ & $\begin{array}{l}\text { *man-o-az-a } \\
\text { *problem-a-ón- } \varnothing \\
\text { *nub-e-os-o }\end{array}$ & $\begin{array}{l}\text { 'hand.AUG' } \\
\text { 'problem.AUG' } \\
\text { 'cloudy' }\end{array}$ \\
\hline
\end{tabular}

In principle, there are two possible approaches to the pattern exemplified in (2). One possibility is to posit some sort of morphotactic restriction preventing nominal stem formatives from occurring inside derivational suffixes, as in (3a). In this view, the stem formative of the base is absent from the underlying phonological representation of the derivative, and the morphological structure of the derivative is faithfully reflected in its surface representation. I shall hereafter refer to analyses of this type as 'purely morphological'.

(3) Purely morphological analysis of (2)

a. Morphotactic restriction ${ }^{4}$

$$
\begin{aligned}
* \mathrm{SF}] \mathrm{DER}] \quad \text { where } & \mathrm{SF}=\text { stem formative } \\
& \mathrm{DER}=\text { derivational suffix }
\end{aligned}
$$

\begin{tabular}{|c|c|c|}
\hline UR & $\llbracket[$ man $\rrbracket o]$ & 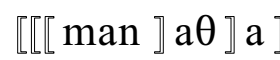 \\
\hline SR & [ má.no ] & [ma.ná.Өa ] \\
\hline & 'hand' & 'hand.AUG' \\
\hline
\end{tabular}

b. Phonological mapping

Alternatively, one can postulate a morphologically sensitive phonological process of deletion applying to unstressed stem-final vowels before vowel-initial suffixes. In (4a) I provide a preliminary statement of this process; the precise conditions listed in the structural description are motivated in $\$ 2.1$ below; tableau (32) offers an optimality-theoretic implementation. In this analysis, which I shall henceforth describe as 'morphophonological', stem-final vowel deletion masks the underlying morphological structure of stem-based derivatives.

(4) Morphophonological analysis of (2)

a. Stem-final vowel deletion

$$
\mathrm{V} \rightarrow \varnothing / \underline{I}_{\text {stem }}^{\sigma_{\mathrm{w}}} \llbracket \text { [suffix } \mathrm{V} \quad \text { (noniterative) }
$$

b. Phonological mapping

$\begin{array}{lll}\text { UR } & \text { [man-o } \rrbracket & \llbracket[\text { man-o } \rrbracket \mathrm{a} \theta-\mathrm{a} \rrbracket \\ \mathrm{SR} & {[\text { má.no }]} & {[\text { ma.ná. } \theta \mathrm{a}]} \\ & \text { 'hand' } & \text { 'hand.AUG' }\end{array}$

The alternative presented by these two approaches has of course not gone unnoticed in the literature (e.g. Pensado 1999: 4461). A similar question arises in Italian (Montermini 2003: $\S 2$ ), where Peperkamp (1995) adopts a purely morphological analysis along the lines of (3), whereas Scalise (1983: 74-78, 287ff.; 1994: 105, 151ff.) posits a rule of vowel deletion analogous to (4a). It is therefore rather surprising to observe that the choice between (3) and (4) has scarcely been discussed in mainstream generative work on Spanish. Within this tradition, most linguists have followed Harris $(1983,1985,1991,1992,1996,1999)$ in 
assuming that Spanish denominal derivational suffixes attach to bases obligatorily lacking stem formatives: e.g. Oltra-Massuet and Arregi (2005: notes 8, 29, 30, 33, 38, 45), Roca (1990: 135, 1991: 604, 2005: 358). ${ }^{5}$ The problem calls for closer scrutiny since, as I pointed out above, one cannot describe Spanish stress or Spanish phonotactics without making crucial assumptions about the behaviour of stem formatives.

In this chapter I examine the issue from the viewpoint of Stratal Optimality Theory (StrOT), a version of Optimality Theory (OT) in which morphology-phonology interactions are modelled by means of cyclicity and level segregation, as in Lexical Phonology and Morphology (LPM): see e.g. Bermúdez-Otero (1999, 2003, forthcoming a), Bermúdez-Otero and McMahon (2006), Booij (1996), Inkelas and Zoll (2005), Kiparsky (1998, 2000, 2003), and Orgun (1996), among others. It turns out that, in a highly constrained version of StrOT allowing no more than three phonological levels, the purely morphological analysis of Spanish nominal stem formatives shown in (3) leads to insurmountable difficulties: it creates a stratification paradox involving the two well-known phonological phenomena of diphthongization and depalatalization. In consequence, StrOT forces one to countenance the long-neglected morphophonological hypothesis set out in (4). Gratifyingly, this turns out to be the correct option: morphological arguments independent from diphthongization and depalatalization consistently favour (4) over (3). This result provides strong support for StrOT, which emerges from the trial as an empirically adequate, highly restrictive, and heuristically powerful model of grammar.

The chapter is organized as follows. Section 1 introduces the key principles of StrOT and shows how their application to Spanish requires the postulation of a morphophonological process of stem-final vowel deletion. In section 2, I examine and refute Harris's arguments for the purely morphological analysis of nominal stem formatives: section 2.1 shows that stem-final vowel deletion is motivated independently by the behaviour of verb stems; section 2.2 examines denominal derivation with consonant-initial suffixes; and section 2.3 adduces new evidence to disprove Harris's claim that, in words such as virus 'virus' and brindis 'toast', the final /Vs/ string is an exotic 'word marker' (cf. (1d)). Significantly, the data presented in section 2.3 reveal a previously unrecognized contrast between pseudoplural nouns (e.g. sg. Sócrat-e-s 'Socrates', pl. Sócrat-e-s, dim.sg. Socrat-it-o) and nouns with athematic stems ending in /s/ (e.g. sg. virus, pl. virus, dim.sg. virus-it-o). In addition, the behaviour of pseudoplural bases casts new light on the relative rôles of suffixes and infixes in Spanish diminutive formation. Section 3 comments on the significance of our results.

\section{The view from Stratal Optimality Theory}

\subsection{Principles}

StrOT aims to solve the problem of phonological misapplication in OT assuming no correspondence relationships other than input-output faithfulness; it therefore rejects both output-output correspondence (e.g. Benua 1997) and sympathy (McCarthy 1999). In addition, StrOT generates nonparadigmatic opacity by the same means as cyclic effects (BermúdezOtero 2003: §8; Bermúdez-Otero and McMahon 2006: §3.2). The theory relies on three basic concepts: those of domain, cycle, and level (Bermúdez-Otero forthcoming a: ch. 2).

Phonology may be thought of as a function $\mathscr{P}$ mapping input representations onto the corresponding outputs. In OT, $\mathcal{P}$ is modelled as a pass through GEN and EvAL:

$$
\mathscr{P}(\mathrm{x})=\operatorname{Eval}\left(\mathcal{G}_{e n}(\mathrm{x})\right)
$$

In StrOT, however, $\mathcal{P}$ applies recursively: certain constituents in the morphosyntactic structure of a linguistic expression (or, alternatively, certain operations in its morphosyntactic derivation) define domains for $\mathcal{P}$; each such domain provides the input for an application of $\mathscr{P}$. BermúdezOtero (forthcoming a: ch. 2) argues that the relationship between grammatical structure and 
phonological domains is in fact one of simplification: each phonological domain is exactly coextensive with some grammatical constituent, but not every grammatical constituent defines a phonological domain (cf. Inkelas 1990, Orgun 1996). ${ }^{6}$ Within the nested hierarchy of phonological domains associated with any linguistic expression, $\mathcal{P}$ applies cyclically in the sense of Chomsky and Halle (1968: 15). However, domains associated with different types of grammatical constituent (or, alternatively, with different types of grammatical operation) may invoke different rankings of CON: it is in this sense that domains are said to belong to different 'levels'. Thus, for example, if a linguistic expression $e$ has the domain structure shown in (6a), where the subscript indices denote the level to which each domain belongs, the surface representation of $e$ will be specified by the composite function (6b).

(6) a. $e=[\mathrm{c}[\mathrm{b}[\mathrm{a} x]][\mathrm{b}[\mathrm{a} y] z]]$

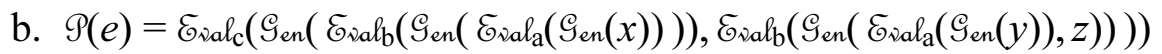

In principle, this theoretical programme could be implemented in several ways. BermúdezOtero (forthcoming a) is primarily concerned with providing a highly restrictive version of StrOT that will curb the complexity of opacity effects and facilitate the acquisition of opaque interactions. This is best achieved in two ways: by limiting the number of phonological levels within the grammar, and by constraining the ascription of grammatical categories to phonological levels. Therefore, following a long tradition of research both within and outside LPM, Bermúdez-Otero (forthcoming a) adopts the hypothesis that, universally, grammars distinguish just three phonological levels: the stem level (SL), the word level (WL), and the phrase level (PL); see also Kiparsky $(1998,2000,2003)$. Within this version of StrOT, the relationship between morphological constructions and phonological levels is regulated by principles that refer to three key morphological categories: root, stem, and word. In brief, a stem is defined as a form that can provide the base for an inflectional operation; roots cannot be inflected without first undergoing root-to-stem conversion (overtly or covertly), whereas words are fully inflected (i.e. syntactically free).

(7) Morphological categories

\begin{tabular}{|c|c|c|}
\hline & inflectable? & fully inflected? \\
\hline root & & \\
\hline stem & $\checkmark$ & \\
\hline word & $(\checkmark)$ & $\checkmark$ \\
\hline
\end{tabular}

On this basis, the grammar is set up in such a way as to enforce the following correspondences between grammatical constructions and phonological domains (for detailed discussion, see Bermúdez-Otero forthcoming a: ch. 2):

(8) a. Roots do not define phonological domains.

b. A phonological domain associated with an operation of root-to-stem derivation must be stem-level.

c. Every morphological word defines a word-level domain.

d. The highest phrasal category in the linguistic expression defines a phrase-level domain. 
At this point, it is important to note that terms such as 'stem-level' and 'stem-based' are not synonymous: the former refers to the phonological properties of an affix; the latter, to its morphological subcategorization requirements. Thus, an affix is stem-level if it defines phonological domains that invoke the stem-level constraint hierarchy; it is stem-based if it attaches to stems. Thus, an affix may be root-based and stem-level, stem-based and stem-level, stem-based and word-level, etc.; by ( $8 \mathrm{~b})$, however, it cannot be root-based and word-level.

In terms of learnability, the austere implementation of StrOT outlined in this section enjoys significant advantages. First, the phonological domain structure of linguistic expressions remains relatively simple; there is no proliferation of cycles (cf. Orgun 1996). ${ }^{7}$ Secondly, learners with access to the grammatical structure of linguistic expressions can easily discover their phonological domain structure.

\subsection{A stratification paradox?}

However, if scholars like Harris, Roca, and Oltra-Massuet and Arregi are right in their view of Spanish nominal stem formatives, then the StrOT model I have just outlined proves too austere: this section will show that, in a system with no more than three phonological levels, positing underlying representations along the lines of ( $3 \mathrm{~b}$ ) leads to a stratification paradox. The problem arises over the stratal ascription of two well-known phonological phenomena: so-called 'diphthongization' and 'depalatalization'. For the sake of convenience I shall retain these traditional labels here, although, as we shall see presently, in neither case does a phonological process derive surface alternants synchronically from a common underlier.

\subsubsection{Diphthongization}

So-called 'diphthongization' affects a sizable but idiosyncratic set of lexical items that display an alternation between the diphthongs /je, we/ and the mid vowels /e, o/: the diphthongs appear in tonic syllables, the mid vowels elsewhere. See Cole (1995: §6.2) for a survey of LPM analyses, and Eddington (2004: §6.1) for a summary of psycholinguistic approaches.

(9) a. Alternating items

$\begin{array}{llll}{[\text { jér-o }]} & \text { 'iron' } & {[\text { er-ér-o] }} & \text { 'blacksmith' } \\ {[\text { pwért-a }]} & \text { 'door' } & {[\text { port-ér-o }]} & \text { 'doorman' } \\ {[\text { djént-e }]} & \text { 'tooth' } & {[\text { dent-ál- } \varnothing]} & \text { 'dental' } \\ {[\text { mwért-e }]} & \text { 'death' } & {[\text { mort-ál- } \varnothing]} & \text { 'mortal' } \\ {[\theta \text { jé } y-o]} & \text { 'blind' } & {[\theta \text { ey-eðád }-\varnothing]} & \text { 'blindness' } \\ {[\text { nwé } \beta-o]} & \text { 'new' } & {\left[\text { no } \beta \text {-eðá }{ }^{\circ}-\varnothing\right]} & \text { 'novelty' }\end{array}$

b. Nonalternating items

\begin{tabular}{|c|c|c|c|}
\hline 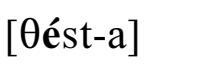 & 'basket' & [Өest-ér-o] & 'basket weaver' \\
\hline$[$ pó $\theta-\mathrm{o}]$ & ‘well' & [po $\theta$-ér-o] & 'well digger’ \\
\hline [a ${ }^{\mathrm{k}} \theta$ iðént-e] & 'accident' & [a ${ }^{\mathrm{k}} \theta$ iðent-ál- $\left.\varnothing\right]$ & 'accidental' \\
\hline [kór-o] & 'chorus' & [kor-ál-Ø] & 'choral' \\
\hline [térk-o] & 'stubborn' & [terk-eðád-Ø] & 'stubbornness' \\
\hline$[\mathrm{mó} \theta-\mathrm{o}]$ & 'young' & {$\left[\mathrm{mo} \theta\right.$-eðá $\left.{ }^{ð}-\varnothing\right]$} & 'youth' \\
\hline
\end{tabular}


I assume that alternating items have two lexically listed allomorphs, whereas nonalternating items have a single underlying representation:

(10) a. Alternating items

$$
\begin{aligned}
& / \mathrm{p}\left\{\begin{array}{c}
\mathrm{o} \\
\mathrm{we}
\end{array}\right\} \mathrm{rt}-\mathrm{a} / \\
& \text { 'door' }
\end{aligned}
$$

b. Nonalternating items

$$
/ \mathrm{po \theta}-\mathrm{o} /
$$

'well'

In this view, diphthongization involves phonological selection between listed allomorphs (e.g. Kager 1996; Mascaró 1996; McCarthy 2002: 152-5, 183-4; Rubach and Booij 2001): the phonological constraint hierarchy preserves the quality of input vowels, but, when given the choice, favours diphthongs in tonic syllables and monophthongs elsewhere. This effect is illustrated in tableau (11), where I use TONIC $\rightarrow$ DIPHTHONGAL as an informal label for whatever context-sensitive markedness constraints favour diphthongs in tonic syllables,

\begin{tabular}{|c|c|c|c|c|c|}
\hline \multirow{2}{*}{ morphology } & \multicolumn{2}{|c|}{ phonology } & \multirow{2}{*}{$\begin{array}{l}\stackrel{5}{z} \\
\stackrel{1}{\Theta}\end{array}$} & \multirow{2}{*}{ 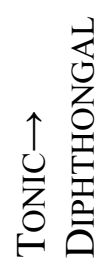 } & \multirow{2}{*}{ 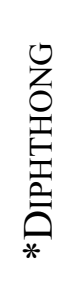 } \\
\hline & input & output & & & \\
\hline \multirow{4}{*}{$\llbracket p\{o, w e\}$ rt-a $\rrbracket$} & \multirow{2}{*}{ /port-a/ } & [pwér.ta] & $* !$ & & $*$ \\
\hline & & [pór.ta] & & $* !$ & \\
\hline & \multirow{2}{*}{ /pwert-a/ } & [pwér.ta] & & & $*$ \\
\hline & & [pór.ta] & $* !$ & $*$ & \\
\hline \multirow{4}{*}{$\llbracket[p\{o, w e\}$ rt-a $\rrbracket$ er-o $]$} & \multirow{2}{*}{ /port-a-er-o/ } & [pwer.té.ro] & $* !$ & $(*)$ & $*$ \\
\hline & & [por.té.ro] & & $(*)$ & \\
\hline & \multirow{2}{*}{ /pwert-a-er-o/ } & [pwer.té.ro] & & $(*)$ & $* !$ \\
\hline & & [por.té.ro] & $* !$ & $(*)$ & \\
\hline \multirow{2}{*}{ 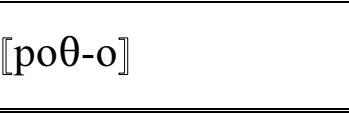 } & \multirow{2}{*}{ /po $\theta-\mathrm{o} /$} & [pwé. $\theta$ o] & $* !$ & & $*$ \\
\hline & & [pó.சo] & & $*$ & \\
\hline \multirow{2}{*}{$\llbracket[$ po $\theta-\mathrm{o}] \mathrm{er}-\mathrm{o}]$} & \multirow{2}{*}{ /po $\theta-\mathrm{o}-\mathrm{er}-\mathrm{o} /$} & [pwe.Өé.ro] & $* !$ & $(*)$ & $*$ \\
\hline & & [po.Өé.ro] & & $(*)$ & \\
\hline
\end{tabular}
whilst *DIPHTHONG is a context-free markedness constraint requiring pure vowels.

For our present purposes, the crucial point is that the selection of the diphthongal allomorph under primary stress overapplies in the presence of certain stress-attracting affixes, such as superlative -ísim-o and the so-called 'evaluative' suffixes, i.e. diminutive $-(e c) i t-o$, augmentative - $a z-o,-o ́ n-\varnothing$, etc.

(12) a. Base

b. Normal nonapplication

c. Overapplication

$\begin{array}{ll}\text { [bwén-o] } & \text { 'good' } \\ {[\text { bon-dád- } \varnothing]} & \text { 'goodness' } \\ {[\text { bwen-1́sim-o] }} & \text { 'best' } \\ {[\text { bwen-á } \theta-o]} & \text { 'good.AUG' } \\ {[\text { bwen-ón- } \varnothing]} & \text { 'good.AUG' } \\ {[\text { bwen-(e } \theta) \text { ít-o] }} & \text { 'good.DIM' }\end{array}$


In StrOT, the overapplication effect in (12c) shows that the domain of diphthongization excludes superlative -ísim- $o$ as well as the evaluative suffixes. Accordingly, we must infer that diphthongization is a stem-level process; that suffixes such as -er-o, $-a l-\varnothing$, and -(i)dad- $\varnothing$ are stem-level; and that superlative -ísim-o and the evaluative suffixes are word-level. ${ }^{9}$

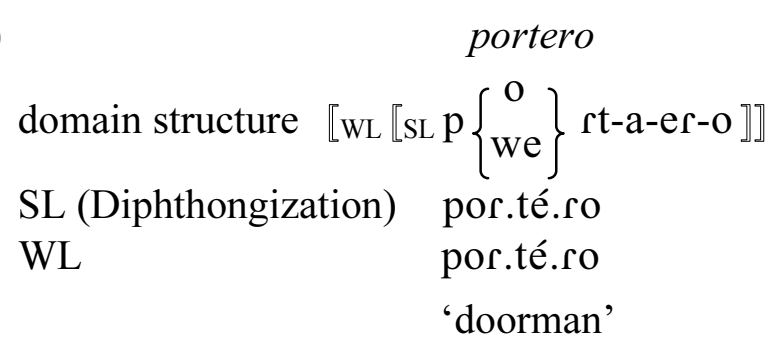

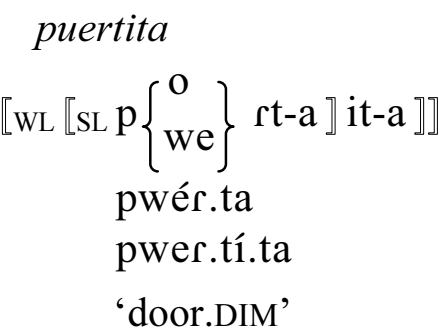

\subsubsection{Depalatalization}

It has long been known that Spanish does not tolerate palatal consonants in domain-final position (Alonso 1945: 96-97). In this chapter the term 'depalatalization' will refer to this phonotactic restriction. The precise nature of the markedness constraint responsible for it need not concern us here; below I shall use *CODA/PAL for convenience.

(14) a. Palatal in onset position [des.ðe.jár] 'to disdain' [don. $\theta$ é.Ka] 'lass' b. Nonpalatal in domain-final position

$\begin{array}{ll}\text { [des.ðén] 'disdain }(\mathrm{N}) & \\ \text { [don. } \theta \text { él] } & \text { 'lad' }\end{array}$

The literature on the subject is abundant: for Harris's last statement on the subject, see Harris (1999); for a recent optimality-theoretic treatment, see Lloret and Mascaró (2005).

It should be noted that, synchronically, the alternants shown in (14) are not derived from a common underlier (Hualde 1989: §6; cf. Lloret and Mascaró 2005). Psycholinguistic experimentation indicates that these alternations are unproductive: native speakers fail to extend them to neologisms (Pensado Ruíz 1997; Eddington 2004: §3.4). This conclusion agrees well with the internal evidence. Observe that, as far as their morphology is concerned, desdén- $\varnothing$ and doncel- $\varnothing$ are perfectly ordinary $e$-stem nouns, as shown by their plural forms: desden-e-s, doncel-e-s; see (1c). After illegal domain-final sequences, however, singular $e$ stem nouns select the /-e/ allomorph of the stem formative; the / $\varnothing /$ allomorph appears only after permissible domain-final strings (Harris 1999; Bermúdez-Otero forthcoming a: ch. 4). ${ }^{10}$ By implication, no singular $e$-stem noun or adjective ends in a sequence that is forbidden domain-finally in the core vocabulary: if the /-e/ formative is absent in that environment, then it is also absent in the plural, showing the stem to be athematic rather than a member of the $e$ class. Examples include partially assimilated loans such as sg. cli[p] 'paper clip' $\sim$ pl. clip-s, not *clip-e-s. ${ }^{11}$ There is thus an altogether natural and predictable relationship of implication between phonological markedness and morphological structure in Spanish nominal morphology: speakers know tacitly that, if a singular noun or adjective is phonotactically deviant, then it cannot belong to one of the core native stem classes and must consequently be athematic. ${ }^{12}$ However, this entails that a hypothetical $e$-stem noun derived from the root /desden-/ would surface as *desde[n]-e, not desdé[n]- $\varnothing$ : see tableau (15). ${ }^{13}$ Synchronically, therefore, the alternation between the verb desdeñ-a-r and the noun desdén- $\varnothing$ is suppletive. 
$(15)$

\begin{tabular}{|c|c|c|c|c|c|c|c|}
\hline \multirow{2}{*}{ morphology } & \multicolumn{2}{|c|}{ phonology } & \multirow{2}{*}{ 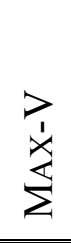 } & \multirow{2}{*}{$\begin{array}{l}> \\
\frac{1}{0} \\
\frac{1}{0}\end{array}$} & \multirow{2}{*}{ 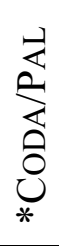 } & \multirow{2}{*}{$\begin{array}{l}\frac{8}{\tilde{J}} \\
\frac{\pi}{2} \\
\frac{1}{Z} \\
\frac{1}{\theta}\end{array}$} & \multirow{2}{*}{ 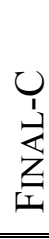 } \\
\hline & input & output & & & & & \\
\hline \multirow{6}{*}{$\begin{array}{l}\text { actual UR } \\
{[\text { desden- }\{\mathrm{e}, \varnothing\} \rrbracket}\end{array}$} & \multirow{3}{*}{ /desden-e/ } & [des.dé.ne] & & & & & $* !$ \\
\hline & & [des.dén] & $* !$ & & $*$ & $*$ & \\
\hline & & [des.dén] & $* !$ & & & & \\
\hline & \multirow{3}{*}{$\leftrightarrow /$ desden- $\varnothing /$} & [des.dé.ne] & & $* !$ & & & $*$ \\
\hline & & [des.dén] & & & $* !$ & $*$ & \\
\hline & & [des.dén] & & & & & \\
\hline \multirow{6}{*}{$\begin{array}{l}\text { counterfactual UR } \\
{[\text { desdej- }\{\mathrm{e}, \varnothing\}]}\end{array}$} & \multirow{3}{*}{ 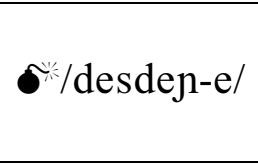 } & $\boldsymbol{\sigma}^{\prime \prime}$ [des.dé.je] & & & & & $*$ \\
\hline & & [des.dén] & $* !$ & & $*$ & & \\
\hline & & [des.dén] & $* !$ & & & $*$ & \\
\hline & \multirow{3}{*}{ /desden- $\varnothing /$} & [des.dé.je] & & $* !$ & & & $*$ \\
\hline & & [des.dén] & & & $* !$ & & \\
\hline & & [des.dén] & & & & $* !$ & \\
\hline
\end{tabular}

Of course, even though the alternations in (14) are lexically listed rather than synchronically derived, depalatalization remains perfectly robust as a principle of allomorph selection and as a static phonotactic restriction, as shown by the evidence of loan adaptation.

In the present context, the interest of depalatalization lies in the fact that it applies not only in phrase-level and word-level domains, but also in sublexical domains which can be proved to be stem-level. The crucial piece of evidence is this: word-final consonants never have palatal alternants before word-level suffixes such as augmentative -az-o or diminutive -(ec)it-o.

(16) a. Base

[don. $\theta$ él] 'lad'

[pjél] 'leather' b. Word-level derivative [don. $\theta$ e.lí.to] *[don. $\theta$ e. Kí.to]

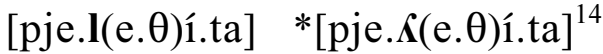

However, if palatals were permitted domain-finally at the stem level, then this type of alternation would be possible. Consider, for example, the derivation of the singular and the diminutive singular forms of a hypothetical $e$-stem noun $/ \mathrm{kanti} \Lambda-\{\mathrm{e}, \varnothing\} /{ }^{15}$ With depalatalization active only at the word level, the result would be an impossible alternation between [kan.tíl] and [kan.ti.Kí.to].

(17) a. Incorrect derivation domain structure

SL ( ${ }^{*}$ CODA/PAL ranked low)

WL (*CODA/PAL ranked high)
SG [wL $[\operatorname{sL} \operatorname{kanti} \kappa-\{\mathrm{e}, \varnothing\}] \rrbracket$ kan.tí $\kappa$

kan.tíl
DIM.SG

[wL [SL $\operatorname{kanti\kappa }-\{\mathrm{e}, \varnothing\}] \mathrm{it}-\mathrm{o}]$

kan.tí $\Lambda$

kan.ti.אí.to

b. Correct derivation

domain structure

SL (*CODA/PAL ranked high)

$[\mathrm{wL}[\mathrm{SL} \operatorname{kanti} \kappa-\{\mathrm{e}, \varnothing\}] \rrbracket$

WL (*CODA/PAL ranked high)

kan.tí.Ke

kan.tí.Ke

[wL [sL $\operatorname{kanti} \kappa-\{\mathrm{e}, \varnothing\}]$ it-o $]$

kan.tí.Ke

kan.ti.Kí.to

We must conclude that palatals are banned domain-finally already at the stem level. 
Note that our analysis correctly predicts that depalatalization cannot cause alternations between the singular and plural forms of $e$-stem nouns. As noted by Harris (1999: 69) and Bermúdez-Otero (forthcoming a: ch. 4, Spanish has a morphological rule, stated informally in (18) below, which requires $e$-stem nominals to take the nonnull allomorph of their stem formative before the plural suffix. The presence of $-e$ - in plurals such as [indú-e-s] 'Hindus' and [réj-e-s] 'kings' fulfils a morphological requirement, not a phonotactic one: *[indú- $\varnothing$-s] and $*[$ rej- $\varnothing$-s] are phonotactically impeccable; cf. [aw.to.ßús] 'bus', [xe.sús] 'Jesus', [sejs] 'six', [bejs] 'beige'. In the same way, constrasts such as [indú-e-s] 'Hindus' vs [menú-s] 'menus' or [réj-e-s] 'kings' vs [xerséj-s] 'pullovers' are symptomatic of a morphological distinction (that between $e$-stems and athematic stems) rather than the operation of a phonological process. See further Bonet (this volume) and Colina (2003a, 2003b).

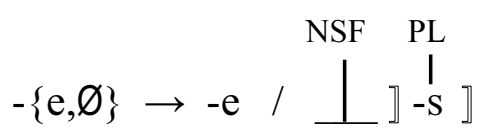

Accordingly, plural $e$-stem nouns and adjectives take the /-e/ formative regardless of the shape of the root. However, if the root ends in a palatal, then the singular form will also select the /-e/ allomorph in order to satisfy *CODA/PAL: see tableau (15).

(19)
Palatal-final root: 'street'
domain structure
SL
SG
$\llbracket \mathrm{wL} \llbracket \mathrm{SL} \mathrm{ka} \Lambda-\{\mathrm{e}, \varnothing\} \rrbracket \rrbracket$
ká.Ke
WL
PL

[wL [SL ka $\Lambda$-e $\rrbracket \mathrm{s} \rrbracket$
ká.Ke
ká.Kes

b. Non-palatal-final root: 'lime'
domain structure
SL
$\llbracket$ wL $\llbracket$ sL kal- $\{\mathrm{e}, \varnothing\} \rrbracket]$
$\mathrm{kal}$
[WL $\llbracket$ SL kal-e $] \mathrm{s} \rrbracket$
ká.le
WL
kal
ká.les

In this sense, depalatalization does not overapply in plural $e$-stems. Although one can use output-output correspondence to account for the absence of alternations such as *[kan.tíl kan.tí.Kes], such a solution relies on a misrepresentation of the morphological facts (pace Lloret and Mascaró 2005). ${ }^{16}$

\subsubsection{The paradox and its solution}

So far, this section has established the following points:

1. diphthongization applies at the stem level;

2. palatal consonants in domain-final position are prohibited at all levels;

3. superlative -ísim-o and the evaluative suffixes are word-level.

In this light, consider now the following data:
(20) a. Base
b. Stem-level derivative
[kwéK-o]
[koК-ár- $\varnothing]$
c. Word-level derivative
[kweর-á $\theta$-o]
'neck'
'collar, necklace'
'neck.AUG'

Paradigms of this type are interesting because they show three phenomena occurring simultaneously: 
1. the root ends in a palatal consonant;

2. the root is subject to the diphthongization alternation;

3. as per (2) above, the stem formative of the base fails to surface in derivationally related forms.

For our purposes, the crucial datum is augmentative cuell-az-o: (20c). It shows overapplication of diphthongization, which is entirely expected since the suffix $-a z-o$ is word-level. The question is: how should we account for the fact that the root-final consonant fails to depalatalize?

Let us first assume that the purely morphological approach outlined in (3) gives us the correct analysis of the behaviour of Spanish nominal stem formatives. If so, the morphological structure of cuell-az-o will be the following:

$$
\llbracket[\llbracket \mathrm{k}\{\mathrm{o}, \mathrm{we}\} \Lambda] \mathrm{a} \theta] \mathrm{o}]
$$

This underlying representation creates a dilemma. If $-a z-o$ is indeed a word-level suffix, then the underlying $/ K /$ will be domain-final in the stem-level cycle and incorrectly undergo depalatalization: see (22a). If, in contrast, $-a z-o$ is already visible to the phonology in the stem-level cycle, then the palatal will be syllabified in onset position and escape depalatalization, but the root-vowel will incorrectly fail to diphthongize: see (22b). In other words, we have a stratification paradox: the augmentative construction can be neither stemlevel nor word-level, yet it must be one of the two.

(22) a. - $a z-o$ is word-level domain structure SL

WL

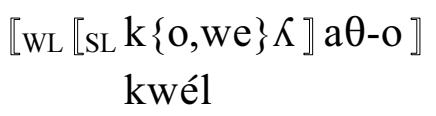

b. $-a z-o$ is stem-level

$$
\begin{aligned}
& \text { [wL [sL k }\{\text { o,we }\} \kappa-a \theta-o \rrbracket \rrbracket \\
& \text { ko.Ká.Өo } \\
& \text { *ko.Ká. } \theta o^{17}
\end{aligned}
$$

And, recall, we cannot solve the problem by turning depalatalization off at the stem level because that would give rise to unattested alternations such as $*[$ kan.tíl $\sim$ kan.ti.Kí.to $]$; see (17).

The alternative hypothesis is that, in the output of the morphology, cuell-az-o has the structure shown in (23); the disappearance of the stem formative of the base is caused by the phonological process of stem-final vowel deletion described in (4a).

$$
\llbracket[\mathrm{k}\{\mathrm{o}, \mathrm{we}\} \Lambda-\mathrm{o}] \mathrm{a} \theta-\mathrm{o} \rrbracket
$$

If we take this view, the stratification paradox evaporates. In the stem-level cycle, the stem formative of the base provides an onset position for the root-final consonant, which accordingly evades depalatalization. In the word-level cycle, the palatal remains in the onset despite stem-final vowel deletion, but stress migrates to the augmentative suffix, causing diphthongization to overapply.

(24) domain structure SL

WL

$$
\begin{aligned}
& \text { [WL [SL } \mathrm{k}\{\mathrm{o}, \mathrm{we}\} \hat{\mathrm{S}} \mathrm{o}] \mathrm{a} \theta-\mathrm{o}] \\
& \text { kwé.Ko } \\
& \text { kwe.Ká.Өo }
\end{aligned}
$$

We must conclude that nominal stem formatives do occur inside derivational suffixation. Thus, the internal logic of StrOT drives one inexorably to reject the view of Spanish nominal 
morphology assumed by Harris, Roca, and Oltra-Massuet and Arregi. Insofar as the endings /-o/, /-a/, and /-e/ can precede derivational suffixes, they cannot be 'word markers' in the sense of Harris (1985), but must be genuine stem formatives: i.e. meaningless morphs added to the root in order to satisfy a 'morphomic' constraint on stem well-formedness (Aronoff 1994). Logically, if a denominal derivative is stem-based (as opposed to root-based), the derivational affix will attach outside the stem formative of the base. More generally, nouns and adjectives belonging to the three core classes (i.e. $o$-stems, $a$-stems, and $e$-stems) turn out to have exactly the same tripartite morphological structure as verbs:

(25) Morphological structure of major-category words (modulo athematic nominals)

a. [Word [Stem [Root__ \SF $\rrbracket \mathrm{INFL} \rrbracket \quad$ where $\mathrm{SF}=$ stem formative

$\mathrm{INFL}=$ inflectional affixes

b. verbs

amábamos

$$
\begin{gathered}
\text { [Word } \llbracket \text { Stem [Root am } \rrbracket \text {-á } \rrbracket \text {-ba } \\
\text { love -SF -PRET.IPFV.IND -1PL } \\
\text { 'we loved' }
\end{gathered}
$$

c. nouns

niños

$$
\begin{gathered}
\llbracket \text { Word [Stem [Root níj } \rrbracket-0 ~]-S ~ \\
\text { boy -SF -PL } \\
\text { 'boys' }
\end{gathered}
$$

In sum, the austere implementation of StrOT outlined in $\S 1.1$ makes very precise predictions about denominal word-formation in Spanish: in particular, it predicts that stem-based denominal derivatives are subject to the phonological process of stem-final vowel deletion formulated in (4a). In the remainder of this chapter I demonstrate that this prediction is, in fact, correct.

\section{The morphological evidence}

Over the years, Harris has grounded his rejection of stem-final vowel deletion on three claims:

1. stem-final vowel deletion has no independent motivation (Harris 1991: footnote 9);

2. stem-final vowel deletion cannot account for the absence of nominal stem formatives before derivational suffixes beginning with a consonant (Harris 1983: 92, 147; 1996: 104);

3. stem-final vowel deletion cannot account for the behaviour of exotic 'word markers' such as -us in vir-us, or -is in brind-is (e.g. Harris 1992: 66, 75).

In this section I show that each of these three claims is false (see also Bermúdez-Otero forthcoming a: ch. 4).

\subsection{Stem-final vowel deletion in verb stems}

Discussing the contrast between the noun [éro-e] 'hero' and its derivatives [ero-ín-a] 'heroine', [ero-1́sm-o] 'heroism', Harris (1991: footnote 9) asserts that the final vowel of the base "is not an integral part of the stem" because "there is no independently motivated rule that would delete such a stem-final vowel". This claim can be easily disproved, for the process of stem-final vowel deletion required to describe denominal derivation operates in exactly the same way in deverbal derivation and verbal inflection.

As is well-known, Spanish verbs fall into three inflectional classes ('conjugations'), characterized by the stem formatives $/-\mathrm{a} /, /-\mathrm{e} /$, and $/-\mathrm{i} /$; these are subject to allomorphic patterns of gradation whose details need not concern us here (see e.g. Harris 1997: 547). The data in (26) show that verb stem formatives surface before consonant-initial derivational 
suffixes. Thus, Harris must stipulate that verb stems are exempt from the putative morphotactic restriction in $(3 a) .{ }^{18}$

$\begin{array}{llll}\text { (26) a. infinitive } & & \text { b. nomen agentis } & \text { c. participle } \\ \text { caz-a-r } & \text { 'hunt' } & \begin{array}{l}\text { caz-a-dor- } \varnothing \\ \text { habl-a-dor- } \varnothing\end{array} & \text { caz-a-d-o } \\ \text { habl-a-r } & \text { 'talk' } & \text { habl-a-d-o } \\ \text { com-e-r } & \text { 'eat' } & \text { com-e-dor- } \varnothing & \text { com-i-d-o } \\ \text { beb-e-r } & \text { 'drink' } & \text { beb-e-dor- } \varnothing & \text { beb-i-d-o } \\ \text { hac-e-r } & \text { 'do' } & \text { hac-e-dor- } \varnothing & \text { hech-o } \\ \text { pon-e-r } & \text { 'put' } & \text { pon-e-dor- } \varnothing & \text { puest-o } \\ \text { abr-i-r } & \text { 'open' } & \text { abr-i-dor- } \varnothing & \text { abiert-o } \\ \text { dec-i-r } & \text { 'say' } & \text { dec-i-dor- } \varnothing & \text { dich-o }\end{array}$

Observe that the derived nomina agentis in (26b) cannot be analysed as departicipial formations in -or- $\varnothing$ because they do not preserve the gradation and suppletion patterns of the corresponding participles. Needless to say, they are not deinfinitival either: rather, they are based on the verb stem. For example, caz-a-dor- $\varnothing$ 'hunter' (pl. caz-a-dor-e-s) has the underlying representation shown in (27).

(27) $\llbracket \mathrm{N}[\mathrm{v} \mathrm{ka} \theta-\mathrm{a} \rrbracket \operatorname{dor}-\{\mathrm{e}, \varnothing\}]$

Consider now the augmentative suffix -ón- $\varnothing$. This can be added not only to nominal stems, but also to verb stems, from which it derives nomina agentis with jocular or derogatory connotations. By principle (8b), these constructions must be stem-based rather than rootbased, since -ón- $\varnothing$ is a word-level suffix: see $\S 1.2 .1$, particularly (12). Moreover, the examples in (28b) are unambiguously deverbal, since they differ morphologically and/or semantically from the corresponding nomina actionis (Lázaro Mora 1999: 4673). Crucially, however, the augmentative nomina agentis lose the stem formative of the base before the initial vowel of the suffix.

(28) a. infinitive

$\begin{array}{ll}\text { acus-a-r } r & \text { 'accuse' } \\ \text { fisg-a-r } & \text { 'pry' } \\ \text { trag-a-r } r & \text { 'swallow' } \\ \text { respond-e-r } & \text { 'answer' }\end{array}$

b. nomen agentis (AUG)

acus-ón- $\varnothing$

fisg-ón- $\varnothing$

trag-ón- $\varnothing$

respond-ón- $\varnothing$ c. nomen actionis acuse, acusación fisgoneo trago respuesta

The contrast between (26b) and (28b) indicates that, in deverbal derivation, the stem formative of the base surfaces before consonant-initial suffixes but is deleted before vowelinitial suffixes, exactly as predicted by (4a).

In fact, stem-final vowel deletion applies in precisely the same way regardless of the syntactic category of the base. First, it does not iterate:

(29) a. Denominal derivation base

héro-e 'hero'

derivative

bacala-o 'cod'

hero-in- $a$, *her-in- $a$ 'heroine'

bacala-it-o, *bacal-it-o ${ }^{19}$ 'cod.DIM'

b. Deverbal derivation

base

derivative

pele-a-( $r)$ 'fight'

pele-ón- $\varnothing$, *pel-ón- $\varnothing$

'quarrelsome'

mare-a-(r) 'make dizzy'

mare-ón- $\varnothing, *$ mar-ón- $\varnothing$

'dizzying' 
Secondly, stem-final vowel deletion does not aply to underlyingly accented vowels. In (30) I provide two examples from denominal derivation. Note that the bases café and papá are athematic stems, not $e$-stems, since their respective plurals are café-s and papá-s. ${ }^{20}$ In both, the final vowel must be underlyingly accented because final stress is a marked pattern for CVCV nouns (see e.g. Roca 1988: 398).
(30) a. base
b. derivative UR SR

\begin{tabular}{|c|c|c|}
\hline 'coffee' & [[ kafé $]$ in-a $]$ & [ka.fe.í.na], *[ka.fí.na] \\
\hline 'Dad' & 【[ papá \it-o ] & [pa.pa.í.to] ${ }^{21}$ \\
\hline
\end{tabular}

The same phenomenon can be observed in verbal inflection. In the preterite imperfective indicative, for example, stress falls consistently on the stem formative. This pattern gives rise to prosodic configurations that are otherwise unattested in the native vocabulary. Notably, second-person plural forms have penultimate stress despite containing a falling diphthong in their final syllable: see (31b). This metrical pattern is impossible in nonverbal forms: e.g. [kom.bój] 'convoy', not*[kóm.boj] (Harris 1983: §4.4.2, 1995: 870; Roca 1988: 398). This contrast indicates that the stress pattern of the preterite imperfective indicative is controlled by the morphology rather than the phonology: more specifically, an allomorphy rule assigns an underlying foot-head to the stem formative. ${ }^{22}$ As expected, the underlyingly accented stem formative fails to delete before the vowel of the tense, aspect, and mood marker.

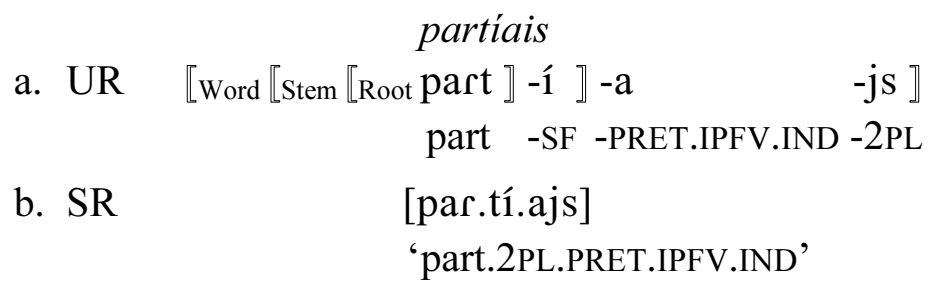

In sum, we cannot concur with Harris (1991: footnote 9) when he asserts that there is no independent motivation for stem-final vowel deletion in Spanish denominal derivation: the same process, subject to identical restrictions, is at work in deverbal derivation and verb inflection. The following tableau provides a possible optimality-theoretic analysis; see Bermúdez-Otero (forthcoming a: ch. 4) for technical discussion.

(32) a. MAX-V\& $\&_{\text {AdjSeg }} M A X-V$

Assign one violation mark if two or more adjacent input vowels lack an output correspondent. ${ }^{23}$

b. MAX-V́

Assign one violation mark for every accented input vowel that lacks an output correspondent.

c. Align(suffix,onset)

If an input vowel $\mathrm{V}$ is initial in a suffix attached to a stem, then assign one violation mark for every segment intervening between the output correspondent of $\mathrm{V}$ and the nearest preceding onset segment. ${ }^{24}$ 
(32) (cont.)

d.

\begin{tabular}{|c|c|c|c|c|c|}
\hline & & 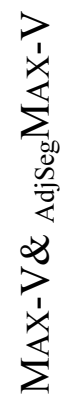 & 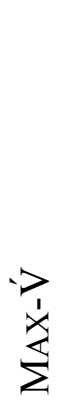 & 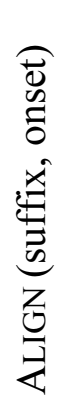 & $\begin{array}{l}> \\
\dot{x} \\
\sum\end{array}$ \\
\hline \multirow{2}{*}{ man-o Stem $\rrbracket a \theta-a$} & ma.no.á. $\theta \mathrm{a}$ & & & $* !$ & \\
\hline & ma.ná.Өa & & & & $*$ \\
\hline \multirow{3}{*}{ bakala-o Stem $]$ it-o } & ba.ka.la.o.í.to & & & $* * !$ & \\
\hline & ba.ka.la.í.to & & & $*$ & $*$ \\
\hline & ba.ka.lí.to & $* !$ & & & $* *$ \\
\hline \multirow{2}{*}{ papá ${ }_{\text {Stem }} \rrbracket$ it-o } & pa.pa.í.to & & & $*$ & \\
\hline & pa.pí.to & & $* !$ & & $*$ \\
\hline
\end{tabular}

\subsection{Denominal derivatives with consonant-initial suffixes}

Our analysis predicts that nominal stem formatives will be able to surface before derivational suffixes, provided that those suffixes are consonant-initial. Is this true? Harris (1983: 92, 147; 1996: 104) claims that it is not, adducing evidence from nomina qualitatis in -dad- $\varnothing$ :

(33) a. base

$\begin{array}{ll}\text { bell-o } & \text { 'beautiful' } \\ \text { buen-o } & \text { 'good' } \\ \text { herman-o } & \text { 'brother' }\end{array}$

b. nomen qualitatis

$\begin{array}{ll}\text { bel-dad- } \varnothing & * \text { bell-o-dad- } \varnothing \\ \text { bon-dad- } \varnothing & * \text { bon-o-dad- } \varnothing \\ \text { herman-dad- } \varnothing & * \text { herman-o-dad- } \varnothing\end{array}$

However, these constructions are altogether irrelevant to the matter at hand, since they are root-based rather than stem-based. Thus, the underlying representation of bon-dad- $\varnothing$ is neither (34a) nor (34b), but (34c).

(34) a. $\quad[$ Stem $\llbracket$ Stem $b\{$ we, o $\}$ n-o $\rrbracket$ dad- $\{\mathrm{e}, \varnothing\} \rrbracket \quad x$

b. $\quad \llbracket$ Stem $[$ Stem $b\{w e, o\} n \rrbracket$ dad- $\{\mathrm{e}, \varnothing\} \rrbracket \quad \boldsymbol{x}$

c. $\llbracket$ Stem $\llbracket$ Root $b\{$ we,$o\} n \rrbracket d a d-\{e, \varnothing\} \rrbracket$

This is confirmed by three facts:

1. The relevant suffix has four allomorphs: -tad- $\varnothing$, -dad- $\varnothing$, -edad- $\varnothing$, and -idad- $\varnothing$. Of these, only -idad- $\varnothing$ remains productive (Santiago Lacuesta and Bustos Gisbert 1999: 4536). In contrast, $-d a d-\varnothing$ is never found in neologisms, but only in words inherited from Latin: e.g. $u \bar{e} r-i t \bar{a} t-e-m>$ ver-dad- $\varnothing$ 'truth', which first underwent intervocalic $-t$ - lenition, and then syncope and apocope (Pharies 2002: 163).

2. Many nomina qualitatis in -dad- $\varnothing$ have bound bases that do not exist as independent stems: e.g. frial-dad- $\varnothing$ 'coldness', mortan-dad- $\varnothing$ 'mortality', ver-dad- $\varnothing$ 'truth'; note the absence of *ver-o, *ver- $a$, *ver-e, or *ver- $\varnothing$ 'true' in modern Spanish. These constructions can only be root-based.

3. Since the allomorph $-d a d-\varnothing$ attaches to roots, StrOT predicts that it will be stem-level, since word-level constructions cannot be root-based: see $(8 \mathrm{~b})$. This prediction proves 
correct, for the addition of $-d a d-\varnothing$ bleeds diphthongization: e.g. [bon.dá ${ }^{ð}$, not *[bwen.dá $\left.{ }^{ð}\right]$; see $\S 1.2 .1$, particularly (12).

Accordingly, the fact that nominal stem formatives do not surface before derivational suffixes is simply due to the absence of productive stem-based denominal constructions with consonant-initial suffixes (Pena 1999: 4337). Since the same is true of Italian (Peperkamp 1995: 210, Montermini 2003: note 3), this state of affairs is likely to represent an inheritance from Latin. However, Spanish does have root-based and word-based nondeverbal constructions with consonant-initial suffixes. As we have just seen, the unproductive suffixal allomorph $-d a d-\varnothing$ is root-based. In contrast, both the deadjectival adverbial suffix -ment-e and the denumeral partitive suffix $-a v-o$ attach to words, i.e. to fully inflected bases; see (7) above. In (35a), for example, we see $-a v-o$ attaching outside the plural ending $-s$ (Pensado 1999: 4461-4462). Interestingly, even though - $a v-o$ begins with a vowel, it does not induce deletion of an immediately preceding vowel in the base: see (35b). This is exactly what one would expect: the phonological process identified in (4a) and formalized in (32c) specifically targets vowel sequences that straddle a stem-suffix boundary.

(35) a.
cardinal
partitive domain structure
SR
[dos. $\theta$ jén.tos]
' 200 '
[Word [Word dos- $\theta$ jent-o-s $\rrbracket a ß-o] ' 200^{\text {th }}$,
[dos. $\theta$ jen.to.sá.ßo]
b. cardinal
partitive domain structure
SR
[ón $\theta-\mathrm{e}]$
[Word [Word on $\theta-\mathrm{e} \rrbracket \mathrm{a} \beta-\mathrm{o} \rrbracket$
[onn.Өe.á.ßo]
' 11 '
' $11^{\text {th }}$

In Spanish, the only possible case of a consonant-initial derivational suffix attaching to a nominal stem is found among the diminutives of bases of the e-class (cf. Peperkamp 1995: 215). Harris (1994: 185) provides the following representation of the morphological structure of malecitos 'bad_thing.DIM.PL', the diminutive of mal-e-s. ${ }^{25}$

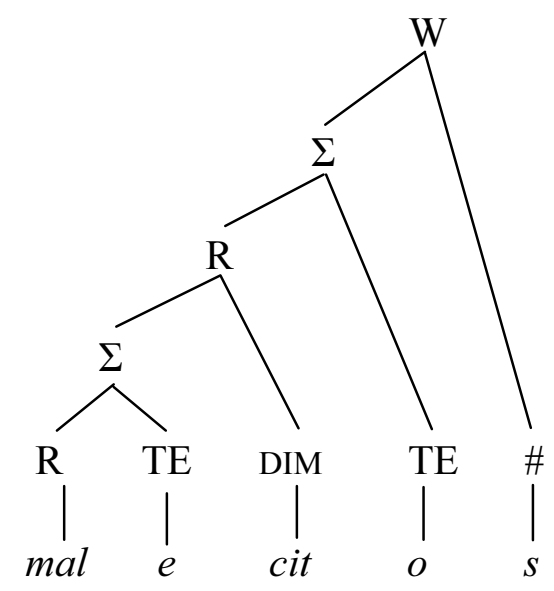

If correct, this parse would once more confirm our predictions, for it shows /-e-/, the stem formative of the base, surfacing before /- $\theta$ it-/, a consonant-initial allomorph of a derivational suffix. Remarkably, Harris does not comment on the inconsistency of his position. 


\subsection{Exotic 'word markers' and nouns ending in $/ \mathrm{s} /$}

Harris's most intriguing argument against stem-final vowel deletion relies on the claim that the set of nominal 'word markers' in Spanish comprises not only the familiar endings $-o,-a$, and $-e / \varnothing$, but also $-i,-u$ and, crucially, $-V-s$ strings (e.g. Harris 1992: 66, 75). These exotic elements appear in loans from Ancient Greek, Latin, English, and other languages (37a), although Harris also provides the same analysis for word-final $-\mathrm{V}-s$ sequences in certain native items (37b). Harris's views have recently been echoed by Bonet (this volume), Lloret and Mascaró (2005: 13), Oltra-Massuet and Arregi (2005: 66), Roca and Felíu (2003: §8), and Roca (2005: 358).

(37) Exotic 'word markers' according to Harris
a. trib-u 'tribe'
güisqu-i 'whisky'
b. Carl-o-s 'Charles'
vir-u-s 'virus'
$l e j-\boldsymbol{o}-\mathbf{s}^{26}$ 'far'
brind-i-s 'toast'

Harris supports his claim with two arguments: one distributional, the other metrical. I deal with the distributional evidence in $\S 2.3 .1$, and with the metrical evidence in $\S 2.3 .2$. The data adduced in $\$ 2.3 .1$ will reveal a three-way morphological contrast among nouns whose singular form ends in /s/: ordinary e-stems, athematic stems ending in $/ \mathrm{s} /$, and pseudoplural words. The evidence of pseudoplurals casts interesting new light on the incidence of suffixation and infixation in Spanish diminutive formation.

\subsubsection{The distributional evidence}

Harris's distributional argument for $-\mathrm{V}-s$ word markers is twofold. First, he notes that the final /Vs/ sequence in words such as virus and Carlos is absent from derivationally related forms: see (38). Obviously, stem-final vowel deletion cannot explain this fact, since it only applies when vowels are immediately adjacent across a stem-suffix boundary. Suppose, however, that the /Vs/ strings in question are word markers. In that case, the morphotactic restriction in (3a) automatically takes care of the situation.

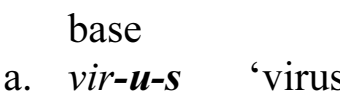
derivative

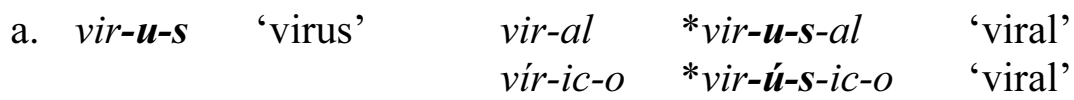
b. brind-i-s 'toast' brind-a-r *brind-i-s-a-r 'to toast'
c. Carl-o-s 'Charles' carl-ist-a *carl-o-s-ist-a 'Carlist'
d. lej-o-s 'far' lej-an-o *lej-o-s-an-o 'distant'
$a-l e j-a-r \quad * a-l e j-o-s-a-r \quad$ 'to distance'

Secondly, Harris observes that, in exactly the same set of words, the plural form is homophonous with the singular:
SG
PL
e.g.
a. [bí.rus] [bí.rus]
muchos virus
'many viruses'
b. [brín.dis] [brín.dis]
muchos brindis 'many toasts'
c. [kár.los] [kár.los]
muchos Carlos
'many Charleses' 
Harris (1992: §4) accounts for this fact by suggesting that the final $-s$ of the word marker occupies the morphological slot allocated to the plural inflection, blocking the insertion of the suffix /-s/. See Harris (1999: footnote 22) for a different statement of the same idea.

However, Harris's distributional argument is invalid because it conflates two heterogeneous word-types. The crucial piece of evidence — which Harris misses - is the contrast between the diminutives of words such as virus and brindis on the one hand, and Sócrates and crisis on the other: compare (40b) with (40c). Once this contrast is taken into consideration, there turn out to be precisely three different types of /s/-final noun in Spanish. The examples shown in (40) are drawn from my own Northern Peninsular idiolect, but they all occur in both Peninsular and Latin American dialects; see the notes for recorded attestations in spontaneous language use.

\begin{tabular}{|c|c|c|c|c|}
\hline $\begin{array}{ll} & \mathrm{SG} \\
\text { a. } & {[1 \text { ris- } \varnothing]}\end{array}$ & $\begin{array}{l}\mathrm{PL} \\
\text { [1́ris-e-s] }\end{array}$ & $\begin{array}{l}\text { DIM } \\
\text { [iris-ít-o] }\end{array}$ & $\begin{array}{l}\text { DIM.PL } \\
\text { [iris-ít-o-s] }\end{array}$ & 'iris, 27 \\
\hline $\begin{array}{l}\text { [bírus] } \\
\text { [bríndis] }\end{array}$ & $\begin{array}{l}\text { [bírus] } \\
\text { [bríndis] }\end{array}$ & $\begin{array}{l}\text { [birus-ít-o] } \\
\text { [brindis-ít-o] }\end{array}$ & $\begin{array}{l}\text { [birus-ít-o-s] } \\
\text { [brindis-ít-o-s] }\end{array}$ & $\begin{array}{l}\text { 'virus, } \\
\text { 'toast',29 }\end{array}$ \\
\hline $\begin{array}{l}\text { [sókrat-e-s] } \\
\text { [krísi-s] }\end{array}$ & $\begin{array}{l}\text { [sókrat-e-s] } \\
\text { [krísi-s] }\end{array}$ & $\begin{array}{l}\text { [sokrat-ít-o] } \\
\text { [kris-e日ít-a] }\end{array}$ & $\begin{array}{l}\text { [sokrat-ít-o-s] } \\
\text { [kris-e } \theta \text { ít-a-s] }\end{array}$ & $\begin{array}{l}\text { 'Socrates',30 } \\
\text { 'crisis }{ }^{31}\end{array}$ \\
\hline
\end{tabular}

The noun in (40a) is an ordinary member of the e-class. In the singular, it selects the null allomorph of the stem formative because the root ends in a permissible domain-final sequence: see (15). In the plural, the morphological rule in (18) requires the presence of the $-e$ allomorph. Accordingly, the forms in (40a) have the following structures in the output of the morphology:

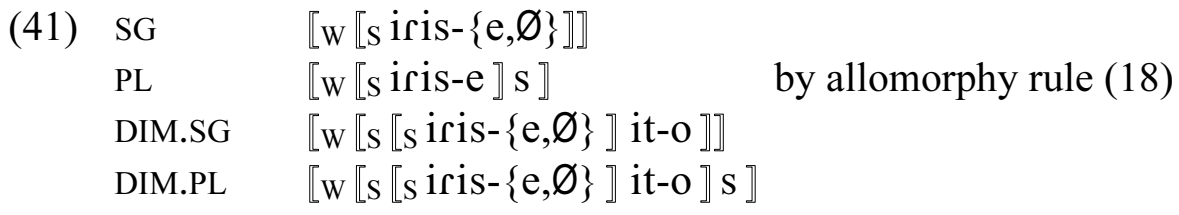

In contrast, the nouns virus and brindis are athematic: they have no stem formative, and in both the stem is coextensive with the root. The sequences /us/ and /is/ are just part of the root and, by the same token, of the athematic stem. Since both the plural suffix /-s/ and the diminutive suffix /-it-o/ are stem-based, they attach outside the stem-final /Vs/ sequence. The homophony between the nondiminutive singular and plural forms is caused by straightforward degemination of the underlying/s-s/ string in the plural form (Contreras 1977). ${ }^{32}$ Thus, words like those shown in (40b) have the following morphological structures:

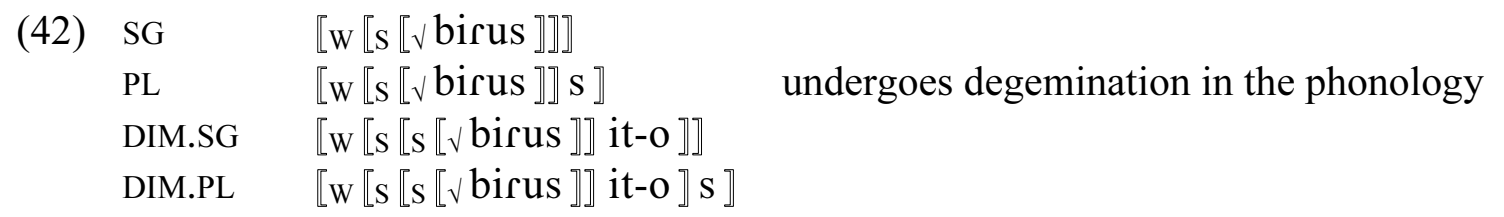

The absence of the string /us/ in derivatives such as vir-al- $\varnothing$ and vir-ic-o, noted in (38), poses no particular difficulty for this analysis. Like nomina qualitatis in -dad- $\varnothing$ (see $§ 2.2)$, these are root-based forms, derived from a bound root allomorph $\llbracket \downarrow$ bir- $\rrbracket$. 
(43) viral $\quad[\mathrm{w} \llbracket \mathrm{s} \llbracket \vee$ bic $\rrbracket$ al- $\{\mathrm{e}, \varnothing\} \rrbracket]$

vírico $\quad[\mathrm{w}[\mathrm{s}[\nu$ bis $] \mathrm{ik}-\mathrm{o}] \rrbracket$

This analysis is corroborated by two pieces of evidence:

1. The suffixes $-a l-\varnothing$ and -ic-o are very commonly found in combination with bound bases: e.g. sider-al- $\varnothing$ 'sidereal', polém-ic-o 'polemical'.

2 . If $-a l-\varnothing$ and $-i c-o$ are root-based suffixes, then they must both be stem-level, since rootto-stem derivation cannot be word-level: see principle (8a). One therefore predicts that the addition of $-a l-\varnothing$, which attracts stress to itself, will bleed diphthongization. This is indeed correct: see (9a).

Significantly, Harris (1992: 76) acknowledges the possibility that derivatives such as vir-al- $\varnothing$ and vir-ic-o may be root-based, but chooses not to pursue it.

Finally, the nouns Sócrat-e-s and crisi-s are pseudoplural. In other words, they are subject to a syntax/morphology mismatch: regardless of their number features in the syntax, in the morphology the stem subcategorizes for the plural suffix /-s/, which occupies the outermost layer of the word. ${ }^{33}$ Accordingly, the final /-s/ of Sócrat-e-s and crisi-s fails to appear inside the diminutive suffix, since the latter attaches to stems, not to words. ${ }^{34}$ Interestingly, the stem of Sócrat-e-s belongs to a core native class, namely the $e$-stems, whereas the stem of crisi-s is athematic. In the output of the morphology, therefore, the forms in (40c) have the following structure:
a. SG $\quad$ Ww $[$ s sokrat-e $] \mathrm{s}]$
/-s/ mismatched with syntactic features ${ }^{35}$
PL $\quad$ [w [s sokrat-e $] \mathrm{s}]$
DIM.SG $\llbracket \mathrm{w}[\mathrm{s}[\mathrm{s}$ sokrat- $\{\mathrm{e}, \varnothing\}]$ it-o $] \rrbracket$
DIM.PL $\quad[\mathrm{w}[\mathrm{s}[\mathrm{s}$ sokrat- $\{\mathrm{e}, \varnothing\}]$ it-o $] \mathrm{s}]$
b. SG $\quad[\mathrm{w}[\mathrm{s}$ krisi $] \mathrm{s}] \quad$ /-s/ mismatched with syntactic features
PL $\quad$ [W [S krisi $] \mathrm{s}]$
DIM.SG [w [s [s krisi \e $\theta$ it-a $\rrbracket \rrbracket$
DIM.PL $\quad[\mathrm{w}[\mathrm{s} \llbracket \mathrm{s}$ krisi $\rrbracket$ e $\theta$ it-a $\rrbracket \mathrm{s} \rrbracket$

Clearly, the existence of diminutive forms such as virus-it-o and brindis-it-o is fatal to Harris's analysis. Insofar as the sequences /us/ and /is/ occur inside derivational suffixes, they cannot be 'word markers' in his sense. Moreover, by placing these sequences outside the stem in virus and brindis, Harris leaves himself no way to account for contrasts such as brindis $\sim$ brindis-it-o vs crisi-s $\sim$ cris-ecit- . .

A lot depends, therefore, on the evidence of forms such as virus-it-o and brindis-it-o. However, there are no valid grounds to question the reliability of these data. Lloret and Mascaró $(2005:$ 12-13, 23) claim that forms of this type do not exist, but this is simply false; diminutives like virus-it-o and brindis-it-o are indisputably attested in records of spontaneous language use by native speakers and, when the pragmatic conditions are right, they occur in high numbers. For example, the relatively high frequency of virus-it-o (see note 28) is obviously the result of felicitous pragmatic conditions: when talking or writing about computers, speakers often have occasion to use the word virus in emotionally charged situations favouring the addition of evaluative suffixes. Other attested derivatives of virus include the augmentatives virus-ot-e and virus-ón- $\varnothing$, all of which are fatal to Harris's analysis. ${ }^{36}$ The absence of these forms from corpora like CREA reflects only the limitations of such corpora, not the competence of native speakers of Spanish (cf. Eddington 2002: §5). 
Similarly, it cannot be objected that the contrast between virus $\sim$ virus-it-o and Sócrat-e-s $\sim$ Socrat-it-o is an artifact of mixing data from disparate dialects. All the diminutive forms listed in (40) occur in my idiolect, in which they are in fact the only possible diminutives of the corresponding bases. In addition, each of these forms can be found in both Peninsular and Latin American dialects.

In sum, the evidence of forms like virus-it-o and brindis-it-o cannot be ruled out of court; to attempt to do so would be irresponsible and would seriously undermine the empirical underpinnings of any inquiry into Spanish nominal classes. However, one can legitimately ask why there is so much variation in the diminutives of paroxytonic singular nouns in /Vs/ with homophonous plurals (see e.g. notes 28 and 29). Bermúdez-Otero (forthcoming b) addresses precisely this question and suggests that this variation is caused by a learnability deficit: the classification of such nouns as athematic stems in $/ \mathrm{s} /$ or as pseudoplurals is underdetermined by the evidence of their inflectional paradigms. Bermúdez-Otero (forthcoming b) explores the ways in which learners circumvent this underdetermination effect by relying on other sources of information: phonotactics (see $\$ 2.3 .2$ below), the identification of 'cranberry morphs', language contact, etc.

The interpretation of the diminutive data raises another question. The existence of words such as those in (45c) indicates that the morph -it- can behave infixally (see Jaeggli 1980; Lázaro Mora 1999: §71.6; Méndez-Dosuna and Pensado 1990).

(45) a. base

[a $\operatorname{cúkar]}$
sugar
[bíktor]
Victor

b. suffixal diminutive

$$
\begin{aligned}
& \text { [a } \theta \text { ukar- }(\theta) \text { ít-o] } \\
& \text { sugar-DIM-SF } \\
& \text { [bik tor- }(\theta) \text { ít-o] } \\
& \text { Victor-DIM-SF }
\end{aligned}
$$

c. infixal diminutive

$$
\begin{gathered}
{[\mathrm{a} \theta \text { uk }<\text { it }>\text { ar }]} \\
\text { sugar }<\text { DIM }> \\
{\left[\text { bi }^{\mathrm{k}} \mathrm{t}<\mathrm{it}>\text { or }\right]} \\
\text { Victor }<\text { DIM }>
\end{gathered}
$$

In $a z u q u<i t>a r$, for example, -it- cannot be anything other than an infix, since the string /ar/ is not a morph: note that the base azúcar- $\varnothing$ is an ordinary $e$-stem noun, as shown by the plural azúcar-e-s.

The infixal behaviour of -it- does not invalidate the conclusions I have drawn from the evidence in (40), since all the diminutive forms presented there are unambiguously suffixal. In virus-it-o, the athematic base virus- is found whole inside the diminutive suffix; the same is true of brindis-it-o. In the case of Sócrat-e-s, infixation would have allowed the pseudoplural $-s$ to be retained in the singular diminutive, yielding either *Socrat $<i t>-e-s$ or *Socrat $<i t-o>-s$; the actual singular form Socrat-it-o arises through the suffixation of -it-o to the stem Sócrat-\{e,Ø\}-. The same argument applies to the singular diminutive cris-ecit-a, not ${ }^{*}$ cris $<i t>i-s$ or ${ }^{*}$ cris $<i t-a>-s$ or ${ }^{*}$ cris $<e c i t-a>-s$. Accordingly, the contrast between virus-it-o and Socrat-it-o cannot be imputed to the alternation between infixal and suffixal strategies in Spanish diminutive formation.

However, the properties of diminutive infixation can explain some intriguing aspects of the behaviour of pseudoplural bases. Consider the following data (cf. Lázaro Mora 1999: §71.6):

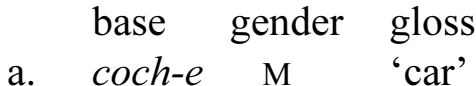
diminutive
b. nub-e F 'cloud'
coch-(ec)it-o, * ${ }^{\text {coch }<i t>-e}$
c. cur-a $\mathrm{M}$
'priest'
$n u b-(e c) i t-a,{ }^{*} n u b<i t>-e$
d. mot-o $\mathrm{F}$
cur $<i t>-a,{ }^{*}$ cur-it-o
'motorbike'
$m o t<i t>-o,{ }^{*}$ mot-it-a 
The evidence of coch-(ec)it-o and nub-(ec)it-a shows that suffixal diminutives belong to the $o$ class when masculine, and to the $a$-class when feminine, regardless of the stem class of the

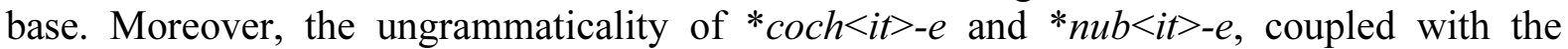
grammaticality of $c u r<i t>-a$ and $m o t<i t>-o$, indicates that the infix -it- subcategorizes for bases where the final syllable nucleus consists of unstressed /o/ or /a/; this hypothesis suggests an obvious scenario of diachronic reanalysis for the rise of the infix from the suffix, and explains the availability of infixation in azuqu<it>ar and Vict<it>or. ${ }^{37}$ We can now account for the fact that diminutives such as $c u r<i t>-a$ and $m o t<i t>-o$ end in the stem formative selected by their bases, instead of the one predicted by their gender (Harris 1999: 76-77): this is because they are the result of the infixation of -it-, rather than the suffixation of -it- $\{o, a\}$.

Compare now the behaviour of the pseudoplural $e$-stem noun Sócrat-e-s with that of the pseudoplural $o$-stem noun Carl-o-s 'Charles':

$\begin{array}{lll}\text { SG } & \text { Sócrat-e-s } & \text { Carl-o-s } \\ \text { PL } & \text { Sócrat-e-s } & \text { Carl-o-s } \\ \text { DIM.SG } & \text { Socrat-it-o } & \text { Carl }<\text { it }>-o-s \\ \text { DIM.PL } & \text { Socrat-it-o-s } & \text { Carl }<\text { it }>-o-s \\ \text { AUG.SG } & \text { Socrat-ot-e } & \text { Carl-ot-e }\end{array}$

Carl-o-s must be a pseudoplural $o$-stem, not an athematic stem in $/ \mathrm{s} /$, since the addition of the augmentative suffix -ot-e yields Carl-ot-e, not ${ }^{*}$ Carlos-ot-e. ${ }^{38}$ However, Carl-o-s differs from Sócrat-e-s in that its singular diminutive is homophonous with its plural diminutive. In other words, Carl-o-s retains its pseudoplural ending $-S$ in the diminutive singular $(\operatorname{Carl}<i t>-O-s)$, whereas Sócrat-e-s does not: the singular diminutive is Socrat-it-o, not *Socrat-it-o-s. Gratifyingly, our hypothesis about the behaviour of the infix -it-predicts this contrast. Sócrat-e-s does not satisfy the subcategorization requirements of the infix -it-because the nucleus of its final syllable is not an unstressed /o/ or /a/. In consequence, the diminutive of Sócrat-e-s has to be formed by adding the suffix -it-o to the stem Sócrat-\{e,Ø\}-, and the pseudoplural ending $-S$ is lost. Carl-o-s, however, does meet the subcategorization requirements of the infix, and the infixation of -it- in Carl<it>-o-S enables the preservation of the pseudoplural ending.

More generally, this analysis of Spanish diminutive formation predicts that the only pseudoplural nouns that can retain their final /-s/ in the diminutive singular are those belonging to the $o$-class (e.g. Carl-o-s $\sim \operatorname{Carl}<i t>-\boldsymbol{o}-s$ ) or to the $a$-class (e.g. mecen-a-s $\sim$ mecen $<i t>-\boldsymbol{a}-s$ 'patron, sponsor'). ${ }^{39}$ In contrast, $e$-stems and athematic stems take the diminutive suffix, rather than the infix, and therefore lose the pseudoplural ending: e.g. Sócrat-e-s $\sim$ Socrat-it-o, crisi-s $\sim$ cris-ecit-a. Forms such as Merced-it-a-s (Lázaro Mora 1999: 4661, Méndez-Dosuna and Pensado 1990) turn out to conform with this prediction once their derivational provenance is properly understood. Spanish has an $e$-stem feminine noun merced- $\varnothing$ 'mercy', whose plural form merced-e-s has been converted into a pseudoplural feminine name: Merced-e-s. The noun merced- $\varnothing$ has an ordinary suffixal diminutive merced-it- $a$, whose plural form merced-it-a-s supplies the diminutive of the name Merced-e-s: i.e. Merced-it-a-s. In this sense, Merced-it$a-s$ is not derived from the pseudoplural name Merced-e-s, either infixally or suffixally.

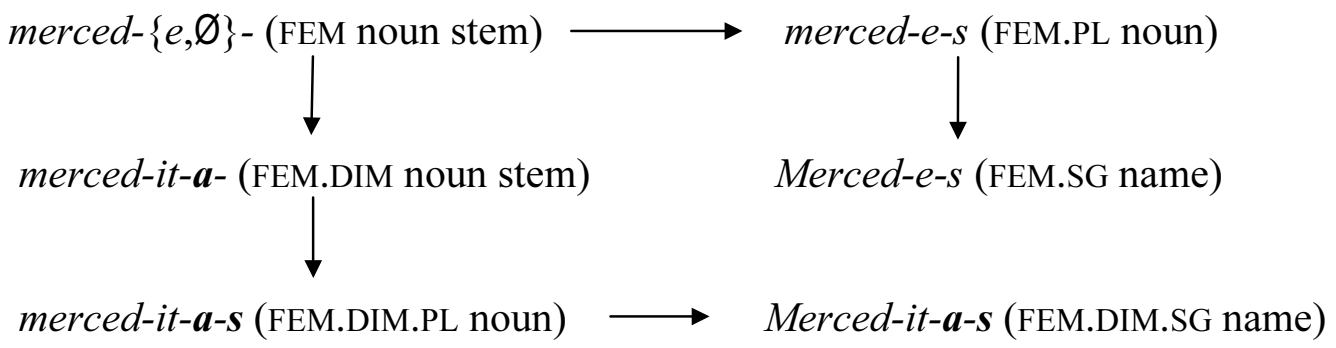


Support for the account outlined in (48) comes from another pseudoplural feminine name, Angel-e-s, derived by conversion from the plural form of a masculine $e$-stem noun: ángel- $\varnothing$ 'angel'. The most common diminutive of this noun is angel-it-o (plural angel-it-o-s), with the default stem formative for a masculine noun. Converting the diminutive masculine plural noun angel-it-o-s into a diminutive feminine singular name would create a mismatch between the stem formative - $O$ - and the name's gender, in addition to the mismatch between the ending $-s$ and the name's number. In these circumstances, Spanish speakers opt to avoid the formative/gender mismatch by deriving the diminutive of the name directly from Angel-e-s. As predicted by my analysis, this results in a suffixal diminutive where the pseudoplural $-s$ is lost: namely, Angel-it-a. ${ }^{40}$

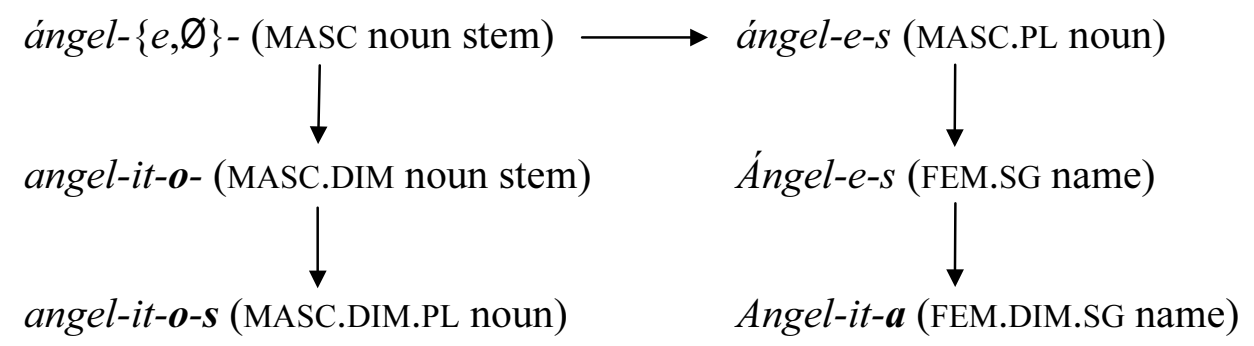

There is independent evidence to confirm that it is the mismatch between the stem formative $-O-$ and feminine gender that prevents the noun angel-it-o-S from being converted into the diminutive of the feminine singular name Ángel-e-s. Note that, alongside angel-it-o-s, the noun ángel- $\varnothing$ has an alternative diminutive plural form, angel-in-e-s, derived by means of the relatively unproductive diminutive suffix -in- $\varnothing$ (see Lang 1990: 107-108). Crucially, the stem formative of angel-in-e-s does not have a default association with masculine gender, and so this noun does undergo conversion into a diminutive feminine singular name: Angel-in-e-s.

One final observation supports the analysis of Merced-it-a-s in (48). James Harris (personal communication) reports that one of his informants has two female relatives whose names are Merced-e-s and Lourd-e-s. The two sisters refer to each other as Merced-it-a-s, with pseudoplural $-s$, but Lourd-it-a, without pseudoplural $-s$. This contrast is explained by the fact that, unlike Merced-e-s, the name Lourd-e-s is based on a French toponym (Lourdes) rather than on a common noun, and so there is no diminutive plural noun *lourd-it-a-s; cf. (48). The diminutive of Lourd-e-s is thus derived directly from the name by adding the suffix $-i t-a$ to the stem Lourd-\{e,Ø\}-, with the result that the pseudoplural $-s$ is lost, as in the case of Socrat-it-o.

\subsubsection{The metrical evidence}

Let us now consider the metrical evidence adduced by Harris (1992: 75) in support of the existence of exotic word markers in Spanish. Harris's argument rests on the observation that Spanish has a phonotactic constraint agains proparoxytonic nouns and adjectives with a closed ultima (see also Roca 1988: 398). As shown in (50b), the domain of this constraint crucially excludes the plural suffix /-s/; the asterisks mark metrically ill-formed items. ${ }^{41}$

a. $\mathrm{SG}$

[ka.ní.ßal], *[ká.ni.ßal] 'canibal'

[sá.ßa.na], *[sá.ßa.nal] 'bed sheet' b. PL

[ka.ní.ßa.les]

[sá.ßa.nas]

Harris notes that singular nouns such as Sócrates and análisis 'analysis' appear to violate this constraint, but the anomaly disappears if the final /Vs/ string is treated as a 'word marker'. My analysis allows for a broadly similar treatment: these items are metrically well-formed if they are parsed as pseudoplurals. 
The previous section provided evidence that Sócrat-e-s is indeed a pseudoplural $e$-stem noun: see (40) and (47). Confirmation that análisi-s is a pseudoplural word with an athematic stem, like $c r i s i-s$, is furnished by the suffixal diminutive analis-it-o. ${ }^{42}$

The premise of Harris's argument is fairly solid. Admittedly, Spanish does have some proparoxytonic singular nouns with closed ultimas that cannot possibly be analysed as pseudoplural: e.g. [bé.ne.ton] 'Benetton'. However, these exceptional items can generally be shown to be partially assimilated loanwords: in the case of [béneton], for example, the plural form [béneton-s] shows that this item remains in the marginal athematic class and has not joined the native $e$-stems. ${ }^{43}$ There appears to be only one genuine exception in the core vocabulary: the $e$-stem noun régimen 'diet', pl. regimen-e-s (Roca 1988: 406, 418; 1990: 149; 2005: 368).

However, Harris's argument has an obvious flaw: the ban on singular proparoxytonic nouns and adjectives with closed ultimas can explain why native speakers of Spanish treat nouns like Sócrat-e-s and análisi-s as pseudoplural, but it says absolutely nothing about the morphological structure of paroxytonic words such as crisi-s, virus, or brindis; cf. (40). In other words, Spanish learners are at liberty to treat the final $/ \mathrm{s} /$ in these items as part of the stem or as a pseudoplural suffix. Indeed, as we saw in $§ 2.3 .1$, contrasts such as brindis-it- $O$ vs cris-ecit-a show that the final /s/ of brindis is parsed as the final segment of an athematic stem, whereas the final /s/ of crisi-s is treated as a pseudoplural suffix. In sum, the metrical evidence does not support Harris's claim that the final string /is/ in brindis is an exotic word marker, and the distributional evidence proves that the claim is, in fact, wrong.

In Bermúdez-Otero (forthcoming b), I turn Harris's metrical argument on its head. I take the contrast between athematic stems ending in $/ \mathrm{s} /$ and pseudoplural words as an established empirical fact. The question then arises as to how Spanish learners manage to acquire the distinction between these two morphological classes. Intriguingly, the distinction is not cued within inflectional paradigms, since both noun types have homophonous singular and plural forms; yet the crucial stem-based word-level derivatives that diagnose the distinction (e.g. suffixal diminutives such as brindis-it-o vs cris-ecit-a) tend to have vanishingly low textfrequencies. Bermúdez-Otero (forthcoming b) argues that, in these circumstances, learners are forced to rely on nonmorphological information. Insofar as proparoxytonic singulars such as Sócrates and análisis are consistently treated as pseudoplural rather than athematic, this would indicate that speakers are able to use phonotactic information to overcome the lack of morphological cues. However, metrical restrictions are less strict in the case of the paroxytones, and this would account for the high levels of variation found among these forms.

We can now conclude section 2.3 by stating that there are no such things as exotic word markers in Spanish. The language has precisely four nominal stem classes:

1. $o$-stems;

2. $a$-stems;

3. $e$-stems, with two subclasses: $e / \varnothing$-stems (e.g. cruz- $\varnothing \sim c r u c-e-s$ ) and $e$-only stems (e.g. cruc-e $\sim$ cruc-e-s);

4. athematic stems.

All four classes contain a small minority of pseudoplural items:

$\begin{array}{llll} & & \text { SG } & \text { DIM/AUG.SG } \\ \text { a. } & o \text {-stem } & {[\text { kárl-o-s] }} & {[\text { karl-ót-e] }} \\ \text { b. } & a \text {-stem } & {[\text { [me日én-a-s] }} & {[\text { me } \theta \text { en-á } \theta-o]} \\ \text { c. } & e \text {-stem } & \text { [sókrat-e-s] } & \text { [sokrat-ít-o] } \\ \text { d. } & \text { athematic } & \text { [análisi-s] } & \text { [analis-ít-o] }\end{array}$


Nothing in the behaviour of nouns ending in /s/ raises problems for an analysis of Spanish denominal derivation based on stem-final vowel deletion, as required by StrOT.

\section{Conclusion}

Scientists and philosophers place high value on theories that make surprising predictions which, unexpectedly, prove correct. This paper has shown that StrOT is such a theory. We have seen that, for over two decades, generative grammarians have espoused a set of tightly interconnected postulates about the behaviour of Spanish nominal stem formatives. They have assumed:

1. that some sort of morphotactic constraint prevents nominal 'word markers' from occurring inside derivational suffixes;

2. that the underlying representation of denominal derivatives such as man-az- $a$ 'hand.AUG' is therefore $\llbracket \llbracket[$ man $\rrbracket a \theta \theta] a \rrbracket$ rather than $\llbracket \llbracket$ man-o $\rrbracket a \theta-a \rrbracket$;

3. that the final /Vs/ sequence in words such as virus is absent from derivatives like viral because it is a word marker and, therefore, incapable of occurring inside derivational affixes.

These assumptions have been reiterated in work as recent as Bonet (this volume), Lloret and Mascaró (2005), Oltra-Massuet and Arregi (2005), Roca and Felíu (2003), and Roca (2005). Against this background, the austere version of StrOT outlined in $\S 1.1$ makes an iconoclastic set of predictions: namely,

1. that nominal stem formatives do in fact occur inside stem-based derivational suffixes;

2. that the correct underlying representation of man- $a z-a$ is $\llbracket[$ man-o $\rrbracket a \theta-a \rrbracket$, and that the stem formative of the base is removed by a phonological process of stem-final vowel deletion;

3. that the absence of the sequence /us/ in viral is not a reflection of the status of /us/ as a 'word marker', but rather of the fact that viral is a root-based derivative.

These predictions follow from the highly constrained way in which morphology and phonology interact in StrOT. Unless one assumes that the morphological structure of cuell-az-o 'neck.AUG' is $\llbracket[\mathrm{k}\{\mathrm{o}, \mathrm{we}\} \hat{\mathrm{C}} \mathrm{-o}] \mathrm{a} \theta-\mathrm{o}]$ rather than $\mathbb{[}[\mathrm{k}\{\mathrm{o}, \mathrm{we}\} \Lambda \rrbracket \mathrm{a} \theta] \mathrm{o}]$, one incurs a stratification paradox: it becomes impossible to assign a coherent phonological domain structure to this word.

However iconoclastic, the predictions of StrOT prove correct. The postulation of a morphologically sensitive phonological process of stem-final vowel deletion is corroborated by three pieces of evidence:

1. the process of stem-final vowel deletion required for the analysis of Spanish denominal derivatives in StrOT is found to operate, under exactly identical conditions, in deverbal derivation and verbal inflection;

2. all denominal derivatives in which the 'theme vowel' of the base seems to disappear before a consonant-initial suffix (e.g. buen-o $\sim$ bon-dad- $\varnothing$ ) prove upon inspection to be root-based rather than stem-based;

3. denominal derivatives in which the base appears to lose its final /Vs/ sequence before a suffix prove to be either root-based (e.g. vírico $[\mathrm{w}[\mathrm{s} \llbracket \downarrow b i c] \mathrm{ik}-\mathrm{o}]]$; cf. virusito $\llbracket \mathrm{w} \llbracket \mathrm{s} \llbracket \mathrm{s}$ bicus $\rrbracket \mathrm{it}-\mathrm{o}] \rrbracket)$ ) or based on a stem from which a pseudoplural ending $-s$ is excluded (e.g. Socratito $[\mathrm{w} \llbracket \mathrm{s}[\mathrm{s}$ sokrat- $\{\mathrm{e}, \varnothing\}] \mathrm{it}-\mathrm{o}] \rrbracket)$ ).

Finally, our discussion of Spanish denominal derivatives has illustrated one of the key advantages of StrOT: its heuristic power. This was specially evident in section 2.3 , as the principles of StrOT enabled us to find our way among the bewildering array of phenomena involved in Spanish diminutive formation. As Harris himself points out in a different connection,

[...T]he problem with this complex set of data - like any other- is that it can be described in a vast number of ways that cannot be immediately rejected on a priori grounds. Discussion becomes interesting only when and to the extent that a restrictive theory, supported empirically by (perhaps few but compelling) crucial cases, radically reduces the available descriptive options.

(Harris 1997: 552) 


\section{Notes}

${ }^{1}$ This paper has benefited from comments, suggestions, and criticism from Eulàlia Bonet, Sonia Colina, Martin Durrell, James Harris, Richard Hogg, Fernando Martínez-Gil, Fabio Montermini, John Payne, Iggy Roca, Anna Thornton, Nigel Vincent, two anonymous reviewers, and the participants of the conference Deponency and morphological mismatches organized by the Surrey Morphology Group at the British Academy in London on 16 and 17 January 2006. None of them necessarily agrees with the views expressed here. I alone am responsible for any remaining flaws.

${ }^{2}$ Bosque and Demonte (1999: Fifth Part) provide a wealth of information about Spanish morphology. For a survey of theoretical proposals on Spanish noun and adjective inflection, see Ambadiang (1993: First Part). Spanish adverbs are not inflected, but on the basis of their formal properties they may be assigned to the same morphological classes as nouns and adjectives (Harris 1983: §5.1.1 endnote 1, 1985: endnote 2); this point does not affect the argument below.

${ }^{3}$ In the literature, these suffixes go under many labels, including 'word marker', 'class marker', 'class vowel', 'form-class morpheme', 'theme vowel', 'thematic suffix', 'terminal element', and 'desinence': see Ambadiang (1993: §2.2), Harris (1999: note 3). As will become apparent below, however, the term 'stem formative' reflects their morphological rôle more transparently: in particular, see (25).

${ }^{4}$ In this paper, morphological categories and the phonological domains associated with them are enclosed within hollow brackets. I use solid brackets for phonetic transcriptions and to mark the edges of prosodic categories.

${ }^{5}$ To be precise, Oltra-Massuet and Arregi (2005: note 8) assert that nominal stem formatives do indeed occur inside derivational suffixes but are phonologically null in that environment. Instead of (3a), therefore, Oltra-Massuet and Arregi would assume an allomorphy rule along the lines of (i), applying specifically to nominal stem formatives:

(i) $\mathrm{NSF} \rightarrow /-\varnothing / / \_\rrbracket \mathrm{DER} \rrbracket$ where NSF = nominal stem formative

This qualification is immaterial to our purposes: the question is whether or not Spanish denominal derivation involves the deletion of stem-final vowels before vowel-initial suffixes.

${ }^{6}$ It is vital not to confuse phonological domains, which are arguments of $\mathcal{P}$, with prosodic units such as $\omega, \varphi, I$, or $U$, which are constituents of phonological representations: see Bermúdez-Otero (forthcoming a: ch. 2). Booij and Rubach (1984) draw the same elementary distinction using the terms 'morphological domain' vs 'prosodic domain'.

${ }^{7}$ Insofar as the complexity of the learner's task increases in proportion to the number of steps in the derivation, the most desirable theory is that which allows the minimum number of cycles compatible with the description of all attested opacity effects. This in no way implies that noncyclic approaches to opacity (e.g. Sympathy Theory) are preferable, for such approaches incur learnability costs of their own, which may well be more onerous than those of StrOT. In fact, Bermúdez-Otero (2003) shows that StrOT facilitates the acquisition of opacity effects, whereas Sympathy Theory makes the task harder.

In addition, it is perfectly possible to allow two or more construction-specific cophonologies within a given level (Anttila 2002; Inkelas 1998; Inkelas \& Zoll 1997, 2003; Orgun 1996) without thereby increasing the number of cycles in each derivation. This is because same-level cophonologies are mutually exclusive. For example, consider a language with two stem-level cophonologies SL $a$ and SL $b$. In such a language, the phonological domain structure of a word $x$ consisting of a single stem without overt inflection will be either [wL $[\mathrm{SL} a] \rrbracket$ or [WL [SL $b] \rrbracket$. In other words, $x$ will go through cophonology SL $a$ or through cophonology SL $b$, but not through both. For an illustration, see the discussion of English stem-level cophonologies in Bermúdez-Otero and McMahon (2006: §4). Inkelas and Orgun (1995) advance a similar idea under the label of 'level economy'.

${ }^{8}$ There is variation between buen-ecit-o and buen-it-o depending on dialectal and stylistic factors.

${ }^{9}$ Certain suffixes, notably -ist-a, exhibit symptoms of dual level membership: e.g. [kwént-o] 'tale' [kont-á-r] 'to tell' $\sim$ [kwent-íst-a] 'fabulist', vs [djént-e] 'tooth' $\sim$ [dent-ál- $\varnothing$ ] 'dental' $\sim$ [dent-1́st-a] 'dentist'; see Eddington (2004: 104). Pace Eddington, however, dual level membership is not a problem for StrOT: a suffix may be able to attach at both the stem level and the word level subject only to constraint ( $8 \mathrm{~b})$, whereby a root cannot be the base of a word-level construction. For further discussion of dual level membership, see Giegerich (1999).

Superlative -ísim-o behaves as a stem-level suffix in a few learnèd words typical of highly formal registers: e.g. [bon-ísim-o] 'best', alongside colloquial [bwen-ísim-o]; [no $\beta$-ísim-o] 'newest', alongside [nwe $\beta$-ísimo]; etc. In addition, augmentative -ach-o is exceptional among the evaluative suffixes by being typically stem-

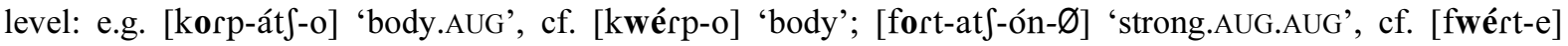
'strong'; etc.

10 As we saw in $\S 0$, there is a minority of $e$-stem nouns that display the /-e/ allomorph in the singular even after a legal domain-final sequence: e.g. $\operatorname{cru}[\theta]-e, \operatorname{inmu}[\mathrm{n}]-\boldsymbol{e}$; see (1c). In these nouns, the underlying representation of the stem formative is $/-\mathrm{e} /$, rather than the more frequent $/-\{\mathrm{e}, \varnothing\} /$.

${ }^{11}$ Clip /klip/ has been nativized segmentally but not phonotactically: Spanish /i/ has been substituted for English $/ \mathrm{I} /$, but /p/ is not tolerated word-finally in the native Spanish vocabulary (see Harris 1992: 66, 1999: 57). 
${ }^{12}$ In Peninsular Spanish the only exception to this generalization is vals- $\varnothing \sim$ vals-e-s 'waltz', plus a tiny handful of nouns ending in /x/, on which see Alonso (1945: footnote 4). Notoriously, the Real Academia de la Lengua has misunderstood this simple fact and throws its prescriptive authority behind artificial creations such as $a ́ l b u[\mathrm{~m}]-\varnothing \sim a ́ l b u[\mathrm{~m}]-e-s$, though without much success: in the playground one consistently hears either álbu[n]$\varnothing \sim a ́ l b u[\mathrm{n}]-e-s$ or álbu[m] álbu[m]-s.

${ }^{13}$ The tableau omits the effects of phrase-level allophonic processes. FINAL-C is the well-known constraint requiring prosodic words to end in a consonant (McCarthy 1993: 176).

${ }^{14}$ Cf. [pe $\boldsymbol{\Lambda}$-éx-o] 'hide', [pe $\boldsymbol{\Lambda}$-i $\theta$-a] 'fleece jacket'. These forms are highly revealing, as the absence of diphthongization in the root-vowel independently confirms that they are stem-level constructions: see $\S 1.2 .1$.

15 Richness of the Base prevents us from stipulating that such nouns do not exist.

16 Although the analysis proposed in Bermúdez-Otero (1999: §3.3.2) did not appeal to output-output correspondence, it too relied on an imperfect understanding on the morphological facts.

${ }^{17}$ Of course, [ko.Ká. $\theta$ o] exists, but only as a derivationally opaque surname, not as the augmentative of [kwé. Ko].

18 Similarly, Oltra-Massuet and Arregi (2005) require a special allomorphy rule specific to nominal bases: see note 5 above.

19 There also exists a suppletive diminutive bacalad-it-o, which has arisen from bacala-it-o through hypercorrection of intervocalic $-d$ - loss.

${ }^{20}$ There formerly existed an $e$-stem plural cafe-e-s, now fallen into desuetude. It occurs, for example, in $E l$ Duende de los Cafees 'The Goblin of the Cafés', the title of a nineteenth-century Spanish newspaper.

${ }^{21}$ Pap-it-o exists, but its base is the hypochoristic papi, not the full form papá.

${ }^{22}$ This allomorphy rule applies to other tenses, but crucially not to the present indicative or present subjunctive. In the latter, the stem formative is not underlyingly accented and, consequently, a phonologically unmarked stress pattern is allowed to emerge. Thus, stress falls consistently on the penultimate syllable nucleus, whether this belongs to the root (e.g. am-a-s [á.mas] 'love.2sg.pres.ind') or to the stem formative (e.g. am-a-mos [a.má.mos] 'love.1pl.pres.ind'). The predictable exception is the second person plural, where the presence of a falling diphthong in the final syllable requires final stress (e.g. am-á-is [a.májs] 'love.2pl.pres.ind'); cf. *[kóm.boj].

Within the framework of Distributed Morphology, Oltra-Massuet and Arregi (2005) posit a rule that accents the syllable nucleus immediately preceding the morph inserted in T. However, they argue that this rule applies to all tense forms, including the present, where, by virtue of a fusion operation, the person and number agreement suffixes realize tense as well (Oltra-Massuet and Arregi 2005: 55). This analysis incorrectly predicts stress on the final syllable of 2sg.pres.ind. verb forms: e.g. *[am-á-s]. To avoid this result, Oltra-Massuet and Arregi (2005: 61) are forced to stipulate an ad hoc operation of grid-mark deletion. This approach obscures the contrast between morphologically driven stress in the imperfective and phonologically driven stress in the present, and misses the emergence-of-the-unmarked effects exhibited by the latter.

${ }^{23}$ For a sequence of adjacent segments as the local domain of a conjunctive constraint, see Lubowicz (2002: $260 \mathrm{ff}$.). In the case of MAX-V\& $\&_{\mathrm{Adj} S \mathrm{Seg}} \mathrm{MAX}-\mathrm{V}$, this is the minimal domain over which both members can be simultaneously evaluated (Lubowicz 2002: footnote 5).

${ }^{24}$ McCarthy (2003) denies the existence of gradient constraints such as (32c). The Spanish evidence may be regarded as a counterexample to this claim. Alternative, ALIGN(suffix,onset) could be 'quantized'; I shall not pursue this option here.

${ }^{25} \mathrm{R}$ stands for 'root', TE for 'terminal element' (see note 3 above), DIM for 'diminutive', \# for 'number', and W for 'word'. Harris (1994: 184) glosses $\Sigma$ as 'uninflected word', but what is an uninflected word, if not a stem? See (7) above.

${ }^{26}$ This is an adverb, but see note 2 .

${ }^{27}$ A high-frequency noun that behaves like (40a) is lápiz 'pencil' in dialects without the phoneme / $\theta /$ : i.e. sg. [lápis], pl. [lápis-e-s], dim.sg. [lapis-ít-o], dim.pl. [lapis-ít-o-s]. For some speakers, iris patterns like brindis in (40b): i.e. sg. [íris], pl. [íris], dim.sg. [iris-ít-o], dim.pl. [iris-ít-o-s]. However, the e-stem plural iris-e-s is widely attested:

El procedimiento de medida consiste en ajustar los irises que permiten el paso de la luz procedente de las fuentes (A), (B), y (C) hasta lograr la igualdad de sensaciones.

Bautista Pulido, J.J. 2002. "Generador-monitor de vídeo para televisión.” Undergraduate dissertation, Universidad de Huelva, La Rábida. Available at http://www.ugr.es/ amroldan/ proyectos/generador_tv/pfc_generador_tv.pdf (accessed on 14 March 2006).

Some Spanish speakers may have acquired the plural iris-e-s under the influence of English irises, particularly in its orthographic form. This does not alter the fact that íris-e-s is a perfectly ordinary $e$-stem plural; cf. [lápis-e-s]. 
28 A search of the World Wide Web by means of Google on 14 March 2006 returned approximately 956 webpages as being in Spanish and containing one or more tokens of virus-it-o: e.g.

Últimamente algún que otro virusito ha aprendido a pillar direcciones de email directamente de los mensajes de news que el usuario tiene en su Outlook.

http://www.forosmix.net/viewtopic-356150.html

Other variants occurred with significantly lower frequencies. Virus-cit-o produced only 10 hits (cf. Ambadiang 1997: 111). There were 327 hits for $<$ virito $>$, but only a small subset corresponded to a diminutive of virus; many pages contained the unrelated surname or nickname Virito. There were no hits at all for vir-ecit-o. See further note 37.

29 A Google search on 14 March 2006 produced 56 hits for brindis-it-o: e.g.

Aunque sea atrasado, desde aquí te enviamos besos y abrazos y el deseo de que sigas tan bella y alegre como siempre. MUAC! Queda pendiente un brindisito.

http://www.genecapriles.net/modules.php? name=News\&file=print\&sid=320

On the same date there were 7 hits for brind-ecit-o (all of them in copies of the same webpage) and none for brindis-cit-o (cf. Ambadiang 1997: 111) or brind-it-o. See further note 37.

30 Estoy a-no-na-da-do. Nunca había leído tanta sabiduría como la que derrocha este Socratito. Te admiro, Sócrates. Eres tan inteligente y sabes tanto. ¡Imbécil! Y tonto, más encima. E ignorante. Parece que nunca te enseñaron a escribir.

http://www.chile.com/tpl/articulo/detalle/masnotas.tpl?cod_articulo=64119 (accessed on 15 January 2006)

31 Los medios de comunicación regionales, más que preocupados por vender periódicos, dadas las importantes noticias de estos días, ridiculizan la crisis, convirtiéndola en "crisis de opereta" o, como mucho, al igual que a nuestras Cortes autonómicas las denominan por estos lares las cortitas, nuestra crisis autonómica la llamarán la crisecita.

\section{Ramón Saura, El País, 1 August 1985}

32 Pace Harris (1992: 76), one does not expect this sequence to be repaired by vowel insertion: it is only initially in the prosodic word that Spanish uses epenthesis to rescue an unsyllabifiable /s/. See Bermúdez-Otero (forthcoming a: ch. 4) for discussion.

33 Spanish pseudoplural words provide an instance of 'extended deponency' in the sense of Baerman et al. (forthcoming). The idea that Spanish has such words is not new (see e.g. Hooper and Terrell 1976, Den Os and Kager 1986, Méndez-Dosuna and Pensado 1990), but so far the distinction between $e$-stems, athematic stems in /s/, and pseudoplurals has never been drawn consistently.

34 Spanish differs from Portuguese, which has two diminutive suffixes: /-in-/, which is stem-based, and /-zin-/, which is word-based. See Rainer (1996: §3), Bachrach and Wagner (2006), Bermúdez-Otero (forthcoming a: ch. 2).

35 I assume that the plural suffix /-s/ triggers allomorphy rule (18) even when mismatched with the syntactic number features of the word.

${ }^{36}$ Here are some examples:

Amigas como les va todo??? Bueno a mi pc se le daño la memoria de RAM y bueno en eso y un virusote que me enviaron pues ya saben, estuve desconectada del mundo... http://vindieselfans.com/foro/viewtopic.php?p=19651\&sid=bec3af59330c1406ac2605b53856bb9a

(accessed on 13 March 2006)

Si algo tiene este antivirus q es notable sobre los demas, es q no t relentiza la pc, tal vez se t puso lenta tu pc por q se puso a vacunar el VIRUSON q tienes http://softonic.es/comment.phtml?id_user=63299 (accessed on 12 March 2005)

37 It seems that, for some speakers, this subcategorization requirement can be relaxed, at least variably. For example, infixal diminutives such as vir $<i t>u s$ and $b r i n d<i t>i s$ are attested, although at very low frequencies. These are strictly ungrammatical in my idiolect.

38 Note the contrast between Carl-o-s $\sim$ Carl-ot-e and virus $\sim$ virus-ot-e (note 36). The following example nicely illustrates the behaviour of Carl-o-s under evaluative derivation:

[...] para conseguir un anuncio hay que hablar con Mercedes y darle comisión a Mercedes, luego a Luisito, a Carlitos, a Carlote, al de allá y al de acá [...] http://www.cedoh.hn2.com/LETICIA.HTML (accessed on 13 March 2006; boldface mine.) 
39 Here is an example of the diminutive mecen $<$ it $>-a-s$ :

Don Jesús optó por prescindir de un mecenas opulento porque los hombres ricos o las instituciones poderosas 'suelen ser exigentes e imponen opiniones'. Era mejor recurrir a muchos mecenitas y a cada uno pedir nada más que 500 pesos.

Rodríguez Alcalá, H. 1987. “Al cumplirse los 40 años de Cuadernos Americanos”. In La incógnita del Paraguay y otros ensayos, H. Rodríguez Alcalá, 179-184. Asunción: Arte Nuevo.

${ }^{40}$ Although Angel-it- $a$ also functions as the diminutive of the name Ángel- $a$, its use as the diminutive of the name Ángel-e-s is well attested:

En abril de 1929, Ángeles Santos o Angelita expone individualmente en el Ateneo de Valladolid. http://antoncastro.blogia.com/2006/032001-el-mundo-y-las-visiones-de-angeles-santos.php (accessed on 10 May 2006)

${ }^{41}$ Among verbs, the metrical constraint against proparoxytones with closed ultimas is violated by 1pl.pret.ipfv.ind. forms like [a.má.ßa.mos], but satisfied by 1.pl.pres.ind. forms like [a.má.mos], not *[á.ma.mos]; cf. 2sg.pres.ind. [á.mas]. This observation confirms our claim that stress is governed by the morphology in the imperfective, but is controlled by phonological defaults in the present: see note 22 above.

42 This is the only possible diminutive form in my idiolect. Unfortunately, I have not been able to compare my intuitions with evidence from spontaneous language use: despite a diligent search, I have found no tokens of análisis in the diminutive.

43 Despues en la zona de atras, pero mas adelante...(xDD se me nota la escasez de palabras lucidas... esto es devido a los carnavales) taran [scilicet estarán] sauberes, jaguares y proses y en la mitad pos [scilicet pues] los Benetons que se jartaran de petar motores renault.

http://foros.ya.com/SForums/\$M=readthread\$TH=135453\$F=26719\$ME=1279988

(accessed on 23 August 2005) 


\section{References}

Alonso, A. 1945. “Una ley fonológica del español.” Hispanic Review 13.91-101.

Ambadiang, T. 1993. La morfología flexiva. Madrid: Taurus.

Ambadiang, T. 1997. "Las bases morfológicas de la formación de diminutivos en español." Verba 24.99-132.

Anttila, A. 2002. "Morphologically conditioned phonological alternations." Natural Language and Linguistic Theory 20.1-41.

Aronoff, M. 1994. Morphology by Itself. Cambridge, MA: MIT Press.

Bachrach, A. and Wagner, M. 2006. "Syntactically driven cyclicity vs. output-output correspondence: the case of adjunction in diminutive morphology." Handout of paper presented at the $29^{\text {th }}$ GLOW Colloquium, Barcelona, 6 April 2006.

Baerman, M., Corbett, G., Brown, D., and Hippisley, A. (eds) forthcoming. Deponency and morphological mismatches [Proceedings of the British Academy]. Oxford: Oxford University Press.

Benua, L. 1997. Transderivational Identity: Phonological Relations between Words. Doctoral dissertation, University of Massachusetts, Amherst. Available at ROA 259, Rutgers Optimality Archive, http://roa.rutgers.edu/.

Bermúdez-Otero, R. 1999. Constraint Interaction in Language Change [Opacity and Globality in Phonological Change]. Doctoral dissertation, University of Manchester / Universidad de Santiago de Compostela. Available at www.bermudez-otero.com/PhD.pdf.

Bermúdez-Otero, R. 2003. "The acquisition of phonological opacity." In Variation within Optimality Theory: Proceedings of the Stockholm Workshop on 'Variation within Optimality Theory', J. Spenader, A. Eriksson and Ö. Dahl (eds), 25-36. Stockholm: Department of Linguistics, Stockholm University. Expanded version available at ROA 593, Rutgers Optimality Archive, http://roa.rutgers.edu/.

Bermúdez-Otero, R. forthcoming a. Stratal Optimality Theory. Oxford: Oxford University Press. Excerpts available at www.bermudez-otero.com/Stratal_Optimality_Theory.htm.

Bermúdez-Otero, R. forthcoming b. "Spanish pseudoplurals: phonological cues in the acquisition of a syntax/morphology mismatch." In Deponency and morphological mismatches [Proceedings of the British Academy], M. Baerman, G. Corbett, D. Brown and A. Hippisley (eds). Oxford: Oxford University Press.

Bermúdez-Otero, R. and McMahon, A. 2006. "English phonology and morphology." In The Handbook of English Linguistics, B. Aarts and A. McMahon (eds). Oxford: Blackwell.

Bonet, E. this volume. "Gender allomorphy and epenthesis in Spanish."

Booij, G. 1996. "Lexical phonology and the derivational residue." In Current Trends in Phonology: Models and Methods, J. Durand and B. Laks (eds), 69-96. Salford: European Studies Research Institute, University of Salford.

Booij, G. and Rubach, J. 1984. "Morphological and prosodic domains in Lexical Phonology." Phonology 1.1-27.

Bosque, I. and Demonte, V. (eds). 1999. Gramática descriptiva de la lengua española. Madrid: Espasa Calpe.

Chomsky, N. and Halle, M. 1968. The Sound Pattern of English. New York: Harper and Row.

Cole, J. 1995. "The cycle in phonology." In The Handbook of Phonological Theory, J.A. Goldsmith (ed), 70-113. Oxford: Blackwell.

Colina, S. 2003a. "The status of word-final [e] in Spanish." Southwest Journal of Linguistics 22(1).87-107.

Colina, S. 2003b. "Diminutives in Spanish: A morphophonological account." Southwest Journal of Linguistics 22(2).45-88.

Contreras, H. 1977. "Spanish epenthesis and stress." University of Washington Working Papers in Linguistics 3.9-33. 
CREA = Real Academia Española. Corpus de referencia del español actual. http://corpus.rae.es/creanet.html.

Den Os, E. and Kager, R. 1986. Extrametricality and stress in Spanish and Italian. Lingua 69.23-48.

Eddington, D. 2002. "Spanish diminutive formation without rules or constraints." Linguistics 40.395-419.

Eddington, D. 2004. Spanish Phonology and Morphology: Experimental and Quantitative Perspectives. Amsterdam: John Benjamins.

Giegerich, H.J. 1999. Lexical Strata in English: Morphological Causes, Phonological Effects. Cambridge: Cambridge University Press.

Harris, J. W. 1983. Syllable Structure and Stress in Spanish: A Nonlinear Analysis. Cambridge, MA: MIT Press.

Harris, J. W. 1985. "Spanish word markers." In Current Issues in Hispanic Phonology and Morphology, F. H. Nuessel (ed), 34-54. Bloomington, IA: Indiana University Linguistics Club.

Harris, J. W. 1991. "The exponence of gender in Spanish.” Linguistic Inquiry 22.27-62.

Harris, J. W. 1992. "The form classes of Spanish substantives." In Yearbook of Morphology 1991, G. Booij and J. van Marle (eds), 65-88. Dordrecht: Kluwer.

Harris, J. W. 1994. "The OCP, Prosodic Morphology, and Sonoran Spanish diminutives: a reply to Crowhurst." Phonology 11.179-190.

Harris, J. W. 1995. "Projection and edge marking in the computation of stress in Spanish." In The Handbook of Phonological Theory, J.A. Goldsmith (ed), 867-887. Oxford: Blackwell.

Harris, J. W. 1996. "The syntax and morphology of class marker suppression in Spanish." In Grammatical Theory and Romance Languages: Selected Papers from the $25^{\text {th }}$ Linguistic Symposium of Romance Languages (LSRL XXV), Seattle, 2-4 March 1995, K. Zagona (ed), 99-122. Amsterdam: John Benjamins.

Harris, J. W. 1997. "There is no imperative paradigm in Spanish." In Issues in the Phonology and Morphology of the Major Iberian Languages, F. Martínez-Gil and A. Morales-Front (eds), 537-557. Washington DC: Georgetown University Press.

Harris, J. W. 1999. "Nasal depalatalization no, morphological wellformedness si; the structure of Spanish word classes." MIT Working Papers in Linguistics 33.47-82.

Hooper, J. B. and Terrell, T. 1976. Stress assignment in Spanish: a natural generative analysis. Glossa 10.64-110.

Hualde, J. I. 1989. Silabeo y estructura morfémica en español. Hispania 72.821-831.

Inkelas, S. 1990. Prosodic Constituency in the Lexicon. New York : Garland.

Inkelas, S. 1998. "The theoretical status of morphologically conditioned phonology: a case study of dominance effects." In Yearbook of Morphology 1997, G. Booij and J. van Marle (eds), 121-155. Dordrecht: Kluwer.

Inkelas, S. and Orgun, C.O. 1995. "Level ordering and economy in the lexical phonology of Turkish." Language 71.763-793.

Inkelas, S., Orgun, C.O., and Zoll, C. 1997. "Implications of lexical exceptions for the nature of grammar. In Constraints and Derivations in Phonology, I. Roca (ed), 393-418. Oxford: Clarendon Press.

Inkelas, S. and Zoll, C. 2003. "Is Grammar Dependence real?" ROA-587, Rutgers Optimality Archive, http://roa.rutgers.edu/.

Inkelas, S. and Zoll, C. 2005. Reduplication: Doubling in Morphology. Cambridge: Cambridge University Press.

Jaeggli, O.A. 1980. "Spanish diminutives." In Contemporary Studies in Romance Languages, F. H. Nuessel (ed), 142-158. Bloomington, IA: Indiana University Linguistics Club.

Kager, R. 1996. "On affix allomorphy and syllable counting." In Interfaces in Phonology, U. Kleinhenz (ed), 155-171. Berlin: Akademie Verlag.

Kiparsky, P. 1998. Paradigm Effects and Opacity. Ms., Stanford University. Forthcoming in Stanford: CSLI Publications. 
Kiparsky, P. 2000. "Opacity and cyclicity." In A Review of Optimality Theory, N.A. Ritter (ed), 351-365. The Linguistic Review 17 (2-4).

Kiparsky, P. 2003. "Syllables and moras in Arabic." In The Syllable in Optimality Theory, C. Féry and R. van der Vijver (eds), 147-182. Cambridge: Cambridge University Press.

Lang, M. F. 1990. Spanish Word Formation: Productive Derivational Morphology in the Modern Lexis. London: Routledge.

Lázaro Mora, F.A. 1999. "La derivación apreciativa." In Gramática descriptiva de la lengua española, I. Bosque and V. Demonte (eds), 4645-4682. Madrid: Espasa Calpe.

Lloret, M.-R. and Mascaró, J. 2005. "Depalatalization in Spanish revised." Ms., Universitat de Barcelona and Universitat Autònoma de Barcelona. Available at ROA 708, Rutgers Optimality Archive, http://roa.rutgers.edu/.

Łubowicz, A. 2002. "Derived environment effects in Optimality Theory." Lingua 112.243-280.

Mascaró, J. 1996. "External allomorphy as emergence of the unmarked." In Current Trends in Phonology: Models and Methods, J. Durand and B. Laks (eds), 473-483. Salford: European Studies Research Institute, University of Salford.

McCarthy, J. J. 1993. "A case of surface constraint violation." Canadian Journal of Linguistics 38.169-195.

McCarthy, J. J. 1999. "Sympathy and phonological opacity." Phonology 16.331-399.

McCarthy, J. J. 2002. A Thematic Guide to Optimality Theory. Cambridge: Cambridge University Press.

McCarthy, J. J. 2003. “OT constraints are categorical.” Phonology 20.75-138.

Méndez-Dosuna, J. and Pensado, C. 1990. "How unnatural is Spanish Victor $\rightarrow$ Vict-it-or? Infixed diminutives in Spanish." In Naturalists at Krems: Papers from the Workshop on Natural Phonology and Natural Morphology (Krems, 1-7 July 1988), J. Méndez-Dosuna and C. Pensado (eds), 89-106. Salamanca: Ediciones Universidad de Salamanca.

Montermini, F. 2003. "Appunti sulla cancellazione di vocale in derivazione." In Scritti di morfologia in onore di Sergio Scalise in occasione del suo $60^{\circ}$ compleanno. A. Bisetto, C. Iacobini, A.M. Thornton (eds), 171-188. Roma: Caissa Italia.

Oltra-Massuet, I. and Arregi, K. 2005. "Stress-by-structure in Spanish." Linguistic Inquiry 36.43-84.

Orgun, C. O. 1996. Sign-Based Morphology and Phonology, with Special Attention to Optimality Theory. Doctoral dissertation, University of California, Berkeley. Available at ROA 171, Rutgers Optimality Archive, http://roa.rutgers.edu/.

Pena, J. 1999. "Partes de la morfología. Las unidades del análisis morfológico." In Gramática descriptiva de la lengua española, I. Bosque and V. Demonte (eds), 4305-4366. Madrid: Espasa Calpe.

Pensado Ruíz, C. 1997. "On the Spanish depalatalization of $/ \mathrm{j} /$ and $/ K /$ in rhymes." In Issues in the Phonology and Morphology of the Major Iberian Languages, F. Martínez-Gil and A. Morales-Front (eds), 595-618. Washington DC: Georgetown University Press.

Pensado Ruíz, C. 1999. "Morfología y fonología. Fenómenos morfofonológicos." In Gramática descriptiva de la lengua española, I. Bosque and V. Demonte (eds), 44234504. Madrid: Espasa Calpe.

Peperkamp, S. 1995. "Prosodic constraints in the derivational morphology of Italian." In Yearbook of Morphology 1994, G. Booij and J. van Marle (eds), 207-244. Dordrecht: Kluwer.

Pharies, D. 2002. Diccionario etimológico de los sufijos españoles y de otros elementos finales. Madrid: Gredos.

Rainer, F. 1996. "Inflection inside derivation: evidence from Spanish and Portuguese." In Yearbook of Morphology 1995, G. Booij and J. van Marle (eds), 83-91. Dordrecht: Kluwer.

Roca, I. 1988. "Theoretical implications of Spanish word stress.” Linguistic Inquiry 19.393-423.

Roca, I. 1990. "Diachrony and synchrony in word stress." Journal of Linguistics 26.133-164. 
Roca, I. 1991. "Stress and syllables in Spanish." In Current Studies in Spanish Linguistics, H. Campos and F. Martínez-Gil (eds), 599-635. Washington DC: Georgetown University Press.

Roca, I. 2005. "Saturation of parameter settings in Spanish stress." Phonology 22.345-394.

Roca, I. and Felíu, E. 2003. "Morphology in truncation: the role of the Spanish desinence." In Yearbook of Morphology 2002, G. Booij and J. van Marle (eds), 187-243. Dordrecht: Kluwer.

Rubach, J. and Booij, G. E. 2001. "Allomorphy in Optimality Theory: Polish iotation." Language 77.26-60.

Santiago Lacuesta, R. and Bustos Gisbert, E. 1999. "La derivación nominal”. In Gramática descriptiva de la lengua española, I. Bosque and V. Demonte (eds), 4505-4594. Madrid: Espasa Calpe.

Scalise, S. 1983. Morfologia lessicale. Padova: Clesp.

Scalise, S. 1994. Morfologia. Bologna: il Mulino. 